\title{
GROWING POLITICAL WILL FROM THE GRASSROOTS: HOW SOCIAL MOVEMENT PRINCIPLES CAN REVERSE THE DISMAL LEGACY OF RULE OF LAW INTERVENTIONS
}

\author{
Fran Quigley*
}

\begin{abstract}
The international community's efforts to promote the rule of law and human rights in developing countries have been largely unsuccessful. This record of disappointment is typically attributed to a lack of political will for reform in the host societies. As a result, an estimated four billion people worldwide are without access to human rights, and suffer without recourse from discrimination, theft, and other forms of physical and emotional harm.

In order to more effectively bring about reform, it is time for rule of law promoters to draw upon the lessons of social science, and particularly the study of social movements. This Article represents the first effort to view the challenge of instilling political will for law reform through the prism of social movement theory and its analysis of events like the U.S. civil rights movement, the South African antiapartheid movement, and the Eastern European democracy movement.
\end{abstract}

* Fran Quigley is a Visiting Professor of Law at the Indiana University School of Law-Indianapolis, associate director of the Indiana-Kenya Partnership/AMPATH, and a staff attorney at Indiana Legal Services. He is a cofounder of the Legal Aid Centre of Eldoret (LACE), a human rights law clinic devoted to representing HIV-positive individuals in western Kenya. Fran has also served as the executive director of the ACLU of Indiana and as a public defender and civil rights attorney.

For their valuable comments on earlier drafts of this Article, the author thanks Florence Wagman Roisman, Daniel H. Cole, Robert W. White, Karen E. Bravo, George E. Edwards, Tanja Chopra, Bill Quigley, Jeanette DickersonPutnam, Ellen Quigley, Linn Hammergren, Stephen Golub and Frank S. Bloch. 
This social movement analysis reveals substantial reason for optimism about achieving significant law reform in developing countries. Rule of law promoters must re-orient their approach and begin supporting the existing and evolving grassroots law reform organizations that mirror in key respects the organizations that have proven to be the catalysts for change in social movements. Properly supported, these organizations can grow and nurture the political will for access to justice that is so desperately needed by billions of people in the developing world.

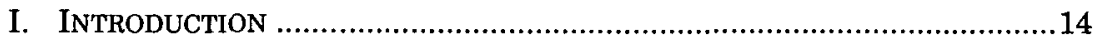

II. THE PoPULAR YET ELUSIVE RULE OF LAW ………............................18

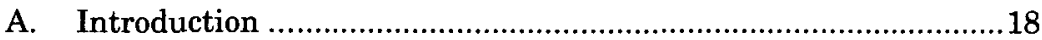

B. Defining the Rule of Law ............................................................

C. The Rule of Law and Development …………….........................20

D. The Limitations of a Rule of Law Approach to Development......24

III. The LAW AS A PAPER Tiger-The CASE OF KenYA................................26

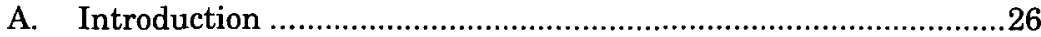

B. Looks Good on Paper-"Rule of Law" in Kenya ..............................28

C. Kenya's Failure to Recognize and Enforce the "Rule of Law"......29

IV. THE WIDESPREAD FAILURE OF EFFORTS TO DEVELOP RULE OF LAW.........36

V. The Failure of Rule of Law Programming...........................................38

VI. THE ABSENCE OF POLITICAL WILl FOR LAW REFORM .............................42

VII. GROWING POLITICAL WILL FOR LAW REFORM: APPLYING THE LESSONS OF SOCIAL MOVEMENTS .......................................................44

A. Introduction-A Social Movement Agenda .....................................44

B. Political Opportunities for Challengers to Engage in Successful Collective Action ..........................................................47

VIII. SELF-IMPOSED EXPECTATIONS BY LOCAL ELITES ....................................48

IX. TRANSNATIONAL SUPPORT .............................................................49

X. GRASSROOTS LEGAL ADVOCATES AND OPPORTUNITIES FOR FRAMING ......58

A. The Framing of Galvanizing Events ............................................61

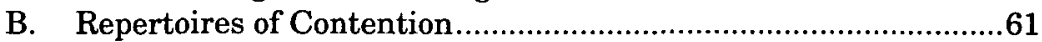

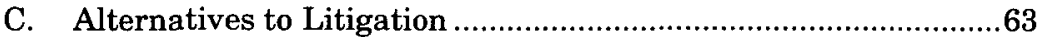

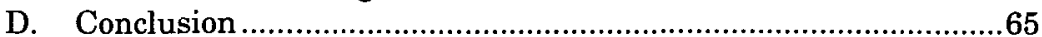

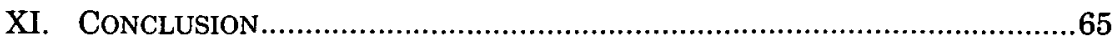

\section{INTRODUCTION}

Leah J. is a slender thirty-year-old Kenyan woman who is the mother of two children, a daughter age six and a son age nine. She is HIV-positive. In August of 2007, her husband, who was also HIVpositive, died. The day she buried her husband on the land of their rural home in the Kerio South region, Leah's father-in-law walked up to her and insisted that she and the children leave immediately. Her 
sisters-in-law sneered to Leah, "We do not have enough land to bury you here, too."

In soft Kiswahili, Leah tells the story of how she and the children fled to the city of Eldoret and stayed in the homes of whichever friends would take them in for a few days at a time. Her husband had not left a will, and she could not gain access to his small pension from his work as a police officer, or to a bank account he had held. Leah could not find work, and she and the children were often hungry and without food. Leah routinely was separated from the children when there was not enough room for everyone at a friend's home. She could not afford mandatory school uniforms or lunch fees, so the children attended school only sporadically. Leah soon learned that her in-laws were trying to sell some of her husband's land. ${ }^{2}$

According to the laws of Kenya, none of this should have happened. The country's Law of Succession Act clearly states that as the surviving spouse, Leah had a life interest in her husband's land and other property. ${ }^{3}$ Kenya is party to a wide array of human rights treaties that aim to protect property rights, to guarantee due process, and to prohibit gender discrimination. ${ }^{4}$ International agencies, including the World Bank, the U.S. Agency for International Development (USAID), and the United Nations Development Programme (UNDP), along with many international nongovernmental organizations, have spent significant resources in Kenya and throughout the developing world in efforts to promote the rule of law. These efforts include billions of dollars devoted to

1. Interview with Leah J. in Eldoret, Kenya (Jan. 8, 2009) (on file with author).

2. Id.

3. Law of Succession Act, (1981) Cap. 160 § 35. (Kenya).

4. See, e.g., African Charter on Human and People's Rights, adopted June 27, 1981, art. 6, 21 I.L.M. 58, at 3 (entered into force Oct. 21 1986) (hereinafter African Charterl (forbidding imprisonment except when under the authority of established laws); Convention on the Elimination of All Forms of Discrimination Against Women, opened for signature Dec. 18, 1979, art. 1-2, 1249 U.N.T.S. 13 (entered into force Sept. 3, 1981) [hereinafter Women's Convention] (prohibiting discrimination on the basis of gender); International Covenant on Economic, Social and Cultural Rights, opened for signature Dec. 16, 1966, art. 1-3, 993 U.N.T.S. 3 (entered into force Jan. 3, 1976) [hereinafter ICESCR] (recognizing property and labor rights); International Covenant on Civil and Political Rights, opened for signature Dec. 16, 1966, art. 1-3, S. Exec. Doc. E, 95-2 (1978), 999 U.N.T.S. 171 (entered into force Mar. 23, 1976) [hereinafter ICCPR] (ensuring political freedom and the right to self-determination). 
building court facilities, buying equipment, and training judges, legislators, and police on the rule of law and human rights. ${ }^{5}$

But when Leah's legal rights were violated, she could not afford access to a lawyer or the courts, and the police and other government officials were not available to intervene to protect her or her children. For Leah, the de jure law respecting her rights was a mere paper tiger, and all the treaty signatures and investment by the international community in Kenya's rule of law had zero effect. Her story is echoed in the experiences of billions of other people in the developing world who are no closer than Leah to achieving access to justice, and as a result suffer through poverty, physical harm, and regular humiliation. ${ }^{6}$

To date, the international community's efforts to instill the rule of law and human rights in developing countries have been guided by the disciplines of law and economics. ${ }^{7}$ Although the goal is a worthy one, these law reform initiatives have been largely unsuccessful, a record of disappointment typically attributed to a lack of political will ${ }^{8}$ for reform in the host countries. Since law and economics have been demonstrably unable to solve the problem of

5. See, e.g., World Bank, Annual Report Year in Review 57 (2008) (World Bank's expenditures in law, justice, and public administration); USAID, Fiscal Year 2008 Agency Financial Report 16 (2008) (USAID's net costs for rule of law and human rights programming); see also World Bank, Project Appraisal Document on a Proposed Credit in the Amount of SDR 12.2 Million to the Republic of Kenya for a Financial and Legal Sector Technical Assistance Project 10-11 (2008) (law reform expenditure in Kenya in the form of an $\$ 18$ million World Bank loan for a Kenyan Governance, Justice, and Law and Order Sector (GIJLOS) reform program that included funds for improving court management systems, education for judges, and support for the Parliament and Attorney General in drafting and enforcement of commercial laws).

6. Comm'n on Legal Empowerment of the Poor, UNDP, Making the Law Work for Everyone 19 (2008) (estimating that four billion people worldwide are excluded from the rule of law).

7. See, e.g., Thomas Carothers, The Rule of Law Revival, 77 Foreign Aff. 95,99 (1998) (arguing that in recent years foreign policy experts increasingly propose that rule of law is the solution to many of the world's troubles).

8. The most accurate definition of the term "political will" when used by commentators in the rule of law and human rights context is the demonstrated credible intent of political actors to take meaningful action towards reform. See, e.g., Sahr J. Kpundeh, Political Will In Fighting Corruption, in Corruption and Integrity Improvement Initiatives in Developing Countries 91, 92 (Sahr J. Kpundeh \& Irene Hors eds., 1998) (defining political will as "the demonstrated credible intent of political actors (elected or appointed leaders, civil society watchdogs, stakeholder groups, etc.) to attack perceived causes or effects of corruption at a systematic level"). 
missing political will, it is time for rule of law implementers to draw upon the lessons of sociology, and particularly the study of social movements. This Article represents the first effort to view the challenge of instilling political will for law reform through the prism of social movement theory, which provides a fresh yet historically and theoretically sound approach to growing the rule of law and human rights in developing countries. ${ }^{9}$

Part I of this Article will summarize the significant historical and theoretical support for the concept of the rule of law, which has led to billions of dollars of investment in programming devoted to promoting human rights and the rule of law in developing countries. Part II will review the situation in Leah J.'s home country of Kenya as a case study of how the prevailing formal law and human rights treaties have little or no impact on the lives of most of the country's citizens, especially women and the poor. Part III outlines the largely unsuccessful record of the prevailing approach to developing rule of law, an approach that focuses on state institutions and a top-down method for promoting reform. Most rule of law practitioners and commentators blame that record of failure on a lack of political will to embrace the called-for changes in the host countries. Finally, Part IV explores how the principles derived from the sociological study of social movements can be applied to create more effective strategies for promoting the rule of law and human rights. That social movement analysis shows that there is substantial reason for optimism about achieving significant law reform in developing countries. If rule of law promoters can re-orient their approach toward supporting existing and evolving grassroots law reform organizations, these organizations can grow and nurture the political will for access to justice that is so desperately needed by Leah J. and billions of others.

9. In this Article, the use of the metaphor of "growing" political will for the rule of law is an intentional choice over similar terms such as "building" or "implementing" the rule of law. As this Article discusses, rule of law efforts have traditionally been dominated by the literal act of building courthouses and other physical or procedural structures based on an external vision of how justice should be applied in developing countries. The study of social movements shows that much better results are likely to be obtained when efforts focus on nurturing the natural process of indigenous advocates employing their superior understanding of local conditions to "grow" their own version of law reform. 


\section{The Popular Yet Elusive RULE OF LAW}

\section{A. Introduction}

The "rule of law" has long been considered to be the ideal format for a governance model that limits state power in an economically and socially efficient manner. Despairing of the limited supply of philosopher-kings, Plato endorsed the rule of law: "[I]f law is the master of the government and the government is its slave, then the situation is full of promise and men enjoy all the blessings that the gods shower on a state."10 The Magna Carta famously promised that no free man would be imprisoned or his property seized "except for lawful judgment of his equals or by the law of the land."1 Max Weber wrote extensively on the role that stable, predictable law plays in enabling economic transactions leading to growth and prosperity. ${ }^{12}$ In modern Western democracy, there is no more enduring maxim than the John Adams-drafted statement in the Constitution of Massachusetts directing that the Commonwealth would be a "government of laws and not of men." ${ }^{13}$ Even the Marxinfluenced twentieth century historian E.P. Thompson boldly pronounced the rule of law as "an unqualified human good."14

As this section will discuss, there is a long-running debate over the meaning of the rule of law that has left the scope of the concept unresolved. Despite this uncertainty, there continues to be strong support for including rule of law programming as a key component of modern multilateral and bilateral investments in the development of poor countries.

10. Plato, The Laws 715d (Trevor J. Saunders trans., Penguin Books 1970) (360 B.C.).

11. Magna Carta, cl. 39 (1215).

12. 2 Max Weber, Economy and Society 641-900 (Guenther Ross \& Claus Wittich eds., 1978) (1914).

13. Mass. Const. part 1, art. XXX.

14. E.P. Thompson, Whigs and Hunters 266 (1975) ("[T] he rule of law itself, the imposing of effective inhibitions on power and the defence of the citizen from power's all-intrusive claims, seems to me to be an unqualified human good."). However, Thompson never backed away from his lifelong insistence that unjust laws need to be challenged. See, e.g., Daniel H. Cole, "An Unqualified Human Good": E.P. Thompson and the Rule of Law, 28 J.L. \& Soc'y 177, 197 (2001) (noting that Thompson "did not cease to rail against capitalism and unjust, class-based laws [even] after he espoused the Rule of Law"). 


\section{B. Defining the Rule of Law}

Despite the broad and enduring agreement on the value of the rule of law, there has not yet been a similar consensus on what exactly the rule of law entails. ${ }^{15}$ The World Bank, the key actor in contemporary rule of law programming, articulates a four-part test: (1) the government itself is bound by the law; (2) every person in society is treated equally under the law; (3) the human dignity of each individual is recognized and protected by law; and (4) justice is accessible to all. ${ }^{16}$

The debate over the meaning of the rule of law tends to come down to the question of whether the law invoked is "thick," encompassing broad social and economic goals, or "thin," meaning a narrow guarantee of specific and predictable procedure. ${ }^{17}$ Some scholars see the rule of law as a "thin" procedural phenomenon, where clear and enforceable laws meet the criteria as long as there is some minimal restraint on the power of the state. ${ }^{18}$ As Joseph Raz argues:

15. See Order in the Jungle, Economist, May 13, 2008, at 95 (including a comment by professor Dani Rodrick asking, "[a]m I the only economist guilty of using the term (rule of law) without having a good fix on what it means? Well, maybe the first to confess it."); see generally Rachel Kleinfeld Belton, Competing Definitions of the Rule of Law 21 (Carnegie Endowment for Int'l Peace, Democracy and Rule of Law Project, Carnegie Papers No. 55, 2005), available at http://www.carnegieendowment.org/files/CP55.Belton.FINAL.pdf (discussing the challenge of defining rule of law by comparing two commonly used definitions: one that emphasizes the function it serves; the other highlighting the institutional elements needed to put it in place).

16. World Bank, Legal and Judicial Reform 1 (2002).

17. See Randall Peerenboom, Let One Hundred Flowers Grow, One Hundred Schools Contend: Debating the Rule of Law in China, 23 Mich. J Int'l L. 472, 472 (2002).

18. See, e.g., Joseph Raz, The Rule of Law and Its Virtue, in the Authority of Law at 210, 210-228 (1979) (Using F.A. Hayek's idea that when law is stripped of technicalities, it means only that the government is bound by fixed rules, which its citizens know and follow, in order to argue that the rule of law is just one of the many virtues a legal system may possess, not to be confused with democracy, justice, and human rights, for example) (1979); Brian Tamanaha, The Lessons of Law and Development Studies, 89 Am. J. Int'l L. 470, 476 (1995) (reviewing the field of law and development to examine the role that law plays in developing countries, and the relationship and influence of modernization theory and dependency on scholarship in law and development); Frank Emmert, Rule of Law in Central and Eastern Europe, 32 Fordham Int'l L.J. 551, 563-68 (2009) (forging a path between thin (which he defines as "formal") and thick (which he defines as "substantive") approaches to rule of law by focusing on the 
[T] he rule of law is just one of the virtues which a legal system may possess and by which it is to be judged. It is not to be confused with democracy, justice, equality (before the law or otherwise) human rights of any kind or the respect for persons or for the dignity of man. A non-democratic legal system, based on the denial of human rights, on extensive poverty, on racial segregation, sexual inequalities, and religious persecution may, in principle, conform to the requirements of the rule of law better than any of the legal systems of the more enlightened Western democracies. This does not mean that it will be better than those Western democracies. It will be an immeasurably worse legal system, but it will excel in one respect: in its conformity to the rule of law. ${ }^{19}$

Most contemporary definitions of rule of law, however, include respect for and enforcement of basic human rights ${ }^{20}$ and most rule of law and development actors now encompass within their plans a broad range of social objectives like health, education and gender equality. ${ }^{21}$

\section{The Rule of Law and Development}

In the $1960 \mathrm{~s}$, as many countries made the transition from colonialism to independence, a "law and development" movement emerged. The movement was based on the concept that the rule of law would be an economic building block for these new nations, with

administrative law traditions of France and Germany, which rest on requirements of legality, legal basis, and judicial review).

19. Raz, supra note 18, at 211 .

20. See The Secretary General, Report of the Secretary General on the Rule of Law and Transitional Justice in Conflict and Post-Conflict Societies, II 10, delivered to the United Nations, U.N. Doc. S/2004/616 (Aug. 23, 2004); USAID, Guide to Rule of Law Country Analysis 5 (2008) (explicitly includes principles of human rights in its definition of rule of law); see also Kleinfield Belton, supra note 15, at 14-15 (discussing the revival of ideas of individual rights in defining the rule of law). Since the Bank and others come to the rule of law question from a perspective focused on its economic value, it should be noted that human rights may have tangible economic value, since there is evidence of a strong empirical link between civil liberties and the performance of government projects. See Jonathan Isham et al., Civil Liberties, Democracy and the Performance of Government Projects, 11 The World Bank Econ. Rev. 219, 228 (1997).

21. See World Bank, World Development Report 2006, at 13 (2006). For a discussion of the trend toward incorporating social goals into development strategies, see Kerry Rittich, The Future of Law and Development: Second Generation Reforms and the Incorporation of the Social, in The New Law and Economic Development 203, 203 (David M. Trubek \& Alvaro Santos eds., 2006). 
human rights and democratic development "spilling over" from economic growth. ${ }^{22}$ As a U.S. law professor who was one of the law and development promoters from that era says now, the premise was that the U.S. model for legal structures could and should be "transplanted" to other nations, chiefly through systems of legal education: "If we could reform Chilean legal education to make it just like ours, it was assumed this would provide what was wanted."23

By the early 1970s, this jurisprudential paternalism had proven so unsuccessful that it was discredited by even its own original proponents. Most notably, Marc Galanter and David Trubek published an article in the Wisconsin Law Review revealingly entitled "Scholars in Self-Estrangement," in which they pronounced the law and development model as "naïve and ethnocentric."

In the early 1990s, law and development made a big comeback under the guise of "the rule of law" or "law reform," foundation of the aid strategies of major international development investors, including most notably, the World Bank, ${ }^{26}$ the InterAmerican Development Bank, ${ }^{27}$ the United Nations Development Program (UNDP), ${ }^{28}$ and bilateral programs such as the U.S. Agency for International Development (USAID). ${ }^{29}$ The key theoretical impetus for rule of law efforts during this era came from the

22. David Trubek, The "Rule of Law" in Development Assistance, in The New Law and Economic Development, supra note 21, at 74, 75, 78.

23. Leah Larson-Rabin, Happenstance and Memory: A Legacy of Law and Development Scholarship and Policy in Legal Education, 25 Wis. Int'l L.J. 209, 212 (2007).

24. Marc Galanter \& David M. Trubek, Scholars in Self-Estrangement: Some Reflections of the Crisis on Law and Development Studies in the United States, 1974 Wis. L. Rev. 1062, 1081 (1974).

25. I will use the terms "rule of law" and "law reform" interchangeably throughout this Article in referring to these development interventions, and will follow the prevailing practice in development discussions of considering these terms to include the concepts of basic human rights, especially freedom from discrimination on the basis of gender or ethnicity, access to judicial systems, and legal accountability of state actors like the police.

26. See Kirsti Samuels, Rule of Law Reform in Post-Conflict Countries: Operational Initiatives and Lessons Learnt iii, 1 (World Bank Social Development Papers, Conflict Prevention and Reconstruction Paper No. 37, 2006).

27. See Christina Biebesheimer, Institute for Latin American Studies, Justice Reform in Latin America and the Caribbean: The IDB Perspective, in Rule of Law in Latin America 99, 100 (Pilar Domingo \& Rachel Seider eds., 2001).

28. UNDP, Bureau of Crisis Prevention and Recovery - Rule of Law, http://www.undp.org/cpr/we_do/security_reform.shtml.

29. USAID, supra note 20 , at 14 . 
neoliberal perspective, often referred to as the "Washington Consensus," which held that private-sector economic development was enabled by strong government institutions providing consistent enforcement of laws, especially in areas of contract and legal title to property. ${ }^{30}$ Indeed, despite the involvement of the global North legal community through such programs as the American Bar Association Rule of Law Initiative, ${ }^{31}$ it is economists and not lawyers who have been the chief source of talking points for the current wave of rule of law promotion. ${ }^{32}$

One such economist is Amartya Sen, the Nobel Laureate economist and one of the most widely recognized proponents of the rule of law. He argues that development is a concept that goes beyond mere economic well-being to embrace political freedom and social opportunities. ${ }^{33}$ A personal witness to the devastating Bengal Famine of 1942, Sen made one of his most compelling arguments for individual freedom in his assertion that no nation with a functioning democracy and free press has ever suffered a famine. ${ }^{34}$ Since information flows freely in those settings and democratic governments must respond to the will-and, presumably, outrage-of the people, widespread suffering is averted..$^{35}$

Sen's conclusion that freedom and economic and social wellbeing are inseparable components of a country's development leads to his embrace of the rule of law:

It is hard to think that development can really be seen independently of its economic, social, political or legal components. We cannot very well say that the development process has gone beautifully even though people are being arbitrarily hanged, criminals go free while law-abiding citizens end up in jail, and so on. This would be as counterintuitive a claim as the corresponding economic one that a country is now highly developed even though it is

30. See, e.g., Erick Jensen, The Rule of Law and Judicial Reform: The Political Economy of Diverse Institutional Patterns and Reformers' Responses, in Beyond Common Knowledge 336, 347 (Erik K. Jensen \& Thomas C. Heller eds., 2003) (noting the role of the "Washington Consensus" in supporting rule of law programming by multilateral development banks in an effort to advance private sector development).

31. American Bar Association, Promoting the Rule of Law, http://www.abanet.org/rol/about.shtml (last visited October 1, 2009).

32. See Larson-Rabin, supra note 23, at 217.

33. Amartya Sen, Development as Freedom 3-11 (2d ed. 2001).

34. Id. at 51 .

35. Id. at 178-186. 
desperately poor and people are constantly hungry .... [So] [i]n answering the query, "What is the role of legal and judicial reform in the development process?", we must at least begin by noting the basic fact that legal development is constitutively involved in the development process, and conceptual integrity requires that we see legal development as crucial for the development process itself. ${ }^{36}$

Peruvian economist Hernando de Soto has made his own well-known argument for the rule of law, a distinctly capitalist celebration of the economic empowerment that flows from clear and enforceable property rights. De Soto reviewed the challenges faced by the poor in countries such as Peru, Haiti, and the Philippines, and concluded that the poor people whom he observed were severely disadvantaged by the absence of an efficient system of regulating property rights. The vacuum of verifiable title to property leads to the inability to obtain credit for assets like houses and small businesses, enforce contracts or conduct trade outside a very small network. ${ }^{37}$ De Soto said that the dysfunctional legal systems of most developing countries stifled entrepreneurship and growth, a point he dramatized by demonstrating that it took 289 days of sustained efforts to legally open a small garment workshop outside Lima. ${ }^{38} \mathrm{De}$ Soto found similar bureaucratic barriers in the other countries he studied, and concluded that clear and legally enforceable titles, along with transparent and straightforward licensing and contract mechanisms, were the keys to development for the poor and their countries. ${ }^{39}$ These same conclusions were echoed recently by the UNDP's Commission on Legal Empowerment of the Poor, which was co-chaired by de Soto and former U.S. Secretary of State Madeline Albright. ${ }^{40}$

These arguments by Sen, de Soto, and others contributed to extensive investments in multilateral and bilateral efforts designed to promote the rule of law. The Vice President and General Counsel of the World Bank reported in 2004 that the Bank had engaged in over 600 rule of law projects. ${ }^{41}$ One calculation that same year

36. Amartya Sen, Address at the World Bank Legal Conference: Role of Legal and Judicial Reform in Development 9-10 (June 5, 2000), available at http://siteresources.worldbank.org/INTLAWJUSTINST/Resources/legalandjudicia l.pdf.

37. Hernando de Soto, The Mystery of Capital 64-66 (2003).

38. Id. at $18-20$.

39. Id. at $56-58$.

40. Comm'n on Legal Empowerment of the Poor, supra note 6, at 15.

41. Robert Danino, Senior Vice President and General Counsel, World 
concluded that the World Bank alone had spent $\$ 2.9$ billion on rule of law projects since $1990,{ }^{42}$ a figure consistent with the Bank's report of spending nearly $\$ 500$ million per year on Rule of Law loans from 2003-2008, and almost $\$ 5.5$ billion per year in a sector it labels "Law and Justice and Public Administration." Accounting Office (which changed its name to the U.S. Government Accountability Office in 2004) reported in 1999 that the U.S. alone had spent $\$ 970$ million on rule of law programming, much of it in Latin America, in just one five-year period in the 1990s. ${ }^{44}$ USAID reported that it spent $\$ 14.3$ million on "rule of law and human rights" in $2007 .{ }^{45}$ These agencies have claimed that their rule of law programming addresses not only economic development and human rights, but also poverty, democratization, and peacemaking. ${ }^{46}$

\section{The Limitations of a Rule of Law Approach to Development}

The combination of extravagant claims and significant investments has led some to argue that the rule of law concept has been oversold. The rule of law is described, usually sarcastically, as "the motherhood and apple pie of development economics," "silver bullet" in development, ${ }^{48}$ the "holy grail"of good governance, ${ }^{49}$ and "the preeminent legitimating political ideal in the world today." It has been pursued "with missionary zeal" and packaged like "a product on late night television. ${ }^{52}$

Bank, Address at the Conference on Human Rights and Development Towards Mutual Enforcement 15 (Mar. 1, 2004), available at http://siteresources.world bank.org/INTLAWJUSTICE/214576-1139604306966/20817164/HumanRights

NewYork030104.pdf.

42. Trubek, supra note 22, at 74 .

43. World Bank Annual Report, supra note 5, at 57.

44. U.S. General Accounting Office, Rule of Law Funding Worldwide For Fiscal Years 1993-1998, at 3 (1999), available at http://www.gao.gov/archive/1999/ns99158.pdf.

45. USAID, supra note 5 , at 16.

46. Samuels, supra note 26 , at 3 .

47. The Economist, supra note 15, at 83.

48. Gordon Barron, The World Bank and Rule of Law Reforms 2 (2005).

49. Jensen, supra note 30 , at 336 .

50. Brian Z. Tamanaha, On the Rule of Law 4 (2004).

51. Rosa Enhrenreich Brooks, The New Imperialism: Violence, Norms and the "Rule of Law," 101 Mich. L. Rev. 2275, 2276 n. 2 (2003).

52. Belton, supra note 15, at 21. 
Thomas Carothers, Vice President for studies at the Carnegie Endowment for International Peace, is one such critic. He argues that despite the investment of rhetoric and dollars in "rule of law" efforts in developing countries, zealous faith in this concept masks the reality of its limits as a promoter of human rights in developing countries. He writes:

Unquestionably, [rule of law] is important to life in peaceful, free and prosperous societies. Yet its sudden elevation as a panacea for the ills of countries in transition from dictatorships or statist economies should make both patients and prescribers wary. The rule of law promises to move countries past the first, relatively easy phase of political and economic liberalization to a deeper level of reform. But that promise is proving difficult to fulfill. ${ }^{53}$

Although generally it is agreed that elements of rule of law are positively associated with economic development, ${ }^{54}$ there is very little in the way of rigorous evaluation of the billions of dollars in investments in rule of law programming. ${ }^{55}$ Carothers and others have pointed out that there is scant evidence that the expensive efforts in recent decades to implement the rule of law have succeeded in improving either the economic or political climates in the host countries. ${ }^{56}$

53. Carothers, supra note 7 , at 95 .

54. See Daniel Kaufman, World Bank Inst., Rethinking Governance 17 (2003); see also Ronald J. Daniels \& Michael Trebilock, The Political Economy of Rule of Law Reform in Developing Counties, 26 Mich. J. Int'l L. 99, 101-104 (2004-2005) (reviewing similar studies that have found a link between rule of law and economic development). But see Richard Posner, Creating a Legal Framework for Economic Development, 13 The World Bank Research Observer 1, 3 (1998) (questioning the direction of causality between legal reform and development and suggesting that development inspires law reform as much as law reform inspires development).

55. See Linn Hammergren, International Assistance to Latin American Justice Programs, in Beyond Common Knowledge, supra note 30, at 290, 301; see also Samuels, supra note 26, at 15 (highlighting the lack of empirical data measuring rule of law outcomes, and the resulting difficulty in crafting accurate indicators); Jensen, supra note 30, at 361-65 (arguing that the current use of impact indicators at the expense of empirical research has led to a lack of credible baseline data against which judicial reform projects can be measured).

56. See Thomas Carothers, Promoting the Rule of Law Abroad 6 (Carnegie Endowment for Int'l Peace, Democracy and Rule of Law Project, Carnegie Papers No. 34, 2003); see also Gary Goodpaster, Law Reform in Developing Countries, 13 Transnat'l. L \& Contemp. Probs. 659, 661 (2003) (pointing out that it is unclear if such reforms result in lasting improvement in the lot of many); Brooks, supra note 51, at 2280-2283 (citing the failure of rule of law initiatives to prevent 


\section{THE LAW AS A PAPER TIGER-THE CASE OF KENYA}

\section{A. Introduction}

From her vantage point in rural Kenya, Leah J. would no doubt agree with the skepticism about the impact of rule of law interventions. Although there is justifiable concern about the absence of rule of law in the developing world as a whole, it is useful to zoom in to look at the example of how rule of law and human rights existor don't-at the ground level in Kenya. Leah J.'s home country offers a stark example of discordance between the law on paper and the true application of rights on the ground.

Kenya is home to a formal court system, is bound by statutes and a constitution, and has signed human rights treaties that protect a broad range of fundamental rights. Despite the hallmarks of rule of law reforms, however, in terms of economic development and civic freedom, Kenya is below average. In the UNDP's 2009 Human Development Index, Kenya ranked 147th out of 182 countries. ${ }^{57}$ Freedom House, a non-governmental organization dedicated to expanding political and economic freedom, and which issues annual rankings of political rights and civil liberties, listed Kenya as "Partly Free" in 2009; only 42 countries were listed with the inferior ranking of "Not Free." 58

The World Bank's Governance Matters study, which evaluates and compares countries on good governance indicators, ranks Kenya in the lowest percentile range for political stability, rule of law, and control of corruption. ${ }^{59}$ Kenyan human rights lawyer Dr. Connie Ngondi Houghton told the country's Commission on Legal Empowerment of the Poor in 2006, "The edifice of the legal and justice system ... is not designed to cater to the interests of the poor,

violence and build an independent judiciary in Russia, Kosovo, and other states transitioning to democracy); Alvaro Santos, The World Bank's Use of the "Rule of Law" Promise in Economic Development, in The New Law and Economic Development, supra note 21, at 253, 285 (pointing to no clear empirical evidence showing the success of judicial reform); Samuels, supra note 26 , at 17 (highlighting the lack of information on long-term outcomes in the field).

57. UNDP, Human Development Index (2009), http:/hdr.undp.org/ en/statistics.

58. Freedom House, Freedom in the World 2009, at 25 (2009), available at http://www.freedomhouse.org/uploads/fiw09/FIW09_Tables\&GraphsForWeb.pdf.

59. World Bank, Governance Matters 2009: Worldwide Governance Indicators 1996-2008 (2009), http://info.worldbank.org/governance/wgi/sc chart.asp. 
women, children, workers, refugees and other vulnerable groups ... $[\mathrm{T}]$ he entire system is broadly insensitive and exclusionary. $\% 0$ Kenyan Vice President Stephen Kalonzo Musyoka, in September 2008 , conceded publicly that the majority of Kenyans have no access to justice through the courts. ${ }^{61}$

With respect to the disconnect between abstract guarantees of justice and the ability of the poor to actually access these guarantees, Kenya represents the norm among developing countries, not the exception. Countries throughout Latin America, Africa, and Eastern Europe struggle to provide access to justice, ${ }^{62}$ and a recent review of African police forces found widespread corruption. ${ }^{63}$ Poor police response, predictably followed by vigilante justice, occurs in much of Africa. ${ }^{64}$ The Kenyan government is not alone in largely ignoring the human rights treaties it has pledged to uphold. Of the 42 countries that Freedom House rated as "Not Free" in its 2009 rankings, all but seven are parties to the ICCPR. ${ }^{65} \mathrm{~A}$ study of African Union states members' responses to recommendations of the African Commission on Human and People's Rights from 1994-2004 showed an overall lack of compliance with the recommendations. ${ }^{66}$ Oona

60. Comm'n on Legal Empowerment of the Poor, UNDP, Summary Report of Kenya National Consultation 5 (2006).

61. Press Release, Stephen Kalonzo Musyoka, Vice President, Kenya, Legal Aid and Awareness Scheme Launch (Sep. 18, 2008) (on file with author).

62. See, e.g., Daniels \& Trebilock, supra note 54, at 123 ("With respect to legal aid and access to justice, in most countries in Latin America, Africa, and central and Eastern Europe, public defender and related legal aid programs were and remain highly incomplete in their coverage, woefully under-resourced, and often quite ad hoc in nature ....."); see also William C. Prillaman, The Judiciary and Democratic Decay in Latin America (2000) (generally examining the inability of reform efforts in Latin America to create a strong, efficient, and accessible judiciary).

63. Alice Hills, Policing Africa 36, 122, 166, 181-82 (2000).

64. Jennifer Widner, Courts and Democracy in Post Conflict Transitions: A Social Scientist's Perspective on the African Case, 95 Am. J. Int'l L 64, 70 (2001).

65. Compare Freedom House, supra note 58, at 22-28 (2009) (list of countries considered "Not Free"), with Office of the U.N. High Commissioner for Human Rights, International Covenant on Civil and Political Rights: Signatories and Parties 1-3 (2009), available at http://treaties.un.org/doc/Publication/ MTDSG/Volume\%20I/Chapter\%20IV/IV-4.en.pdf (listing the parties to the ICCPR).

66. See Frans Viljoen \& Lirette Louw, State Compliance with the Recommendations of the African Commission on Human and People's Rights, 101 Am. J. Int'l L. 1, 4-7 (2007) (noting that in only $14 \%$ of the communications examined did states fully comply with the recommendations of the African Commission). 
Hathaway's quantitative analysis found no human rights treaty for which ratification by a country was associated with that country's engaging in better human rights practices, and several treaties where ratification was actually associated with worse practices. ${ }^{67}$

\section{B. Looks Good on Paper- "Rule of Law" in Kenya}

On paper, the prospects for the rule of law in Kenya look promising: Kenya has a formal court system that dates back to its colonial roots and decides cases based on Kenyan statutory law, Kenyan and English common law, tribal law, and Islamic law. ${ }^{68}$ Its formal judicial system consists of five levels of Magistrates' Courts, a High Court, and a Court of Appeals. ${ }^{69}$ Magistrate courts handle about $90 \%$ of the cases before the judiciary. ${ }^{70}$ An ethnic group's customary law is allowed to apply in civil cases only if it is not "repugnant to justice and morality or inconsistent with any formal law."11 Kadhis' courts rule on the basis of Sharia law and work alongside magistrates in areas with significant Muslim populations. ${ }^{72}$

Kenya is a party to the ICCPR, which prohibits discrimination on the basis of gender, ${ }^{73}$ mandates fair criminal procedures, ${ }^{74}$ and insists on equal rights during and after marriage. ${ }^{75}$ Kenyans are guaranteed these and a generous variety of other rights by virtue of their country's acceding to the ICESCR, ${ }^{76}$ the African Charter, ${ }^{77}$ and the Women's Convention. ${ }^{78}$ Kenya's constitution

67. Oona A. Hathaway, Do Human Rights Treaties Make a Difference?, 111 Yale L.J. 1935, 1976-2000 (2002).

68. Hunton \& Williams, Legalbrief Africa, Customary and Islamic Law and Its Development in Kenya, (Oct. 11, 2004), http://www.legalbrief.co.za/ article.php?story $=20041010212108281$.

69. Id.

70. International Comm'n of Jurists, Kenya: Judicial Independence, Corruption and Reform 36 (2005).

71. The Judicature Act, (1977) Cap. $8 \$ 3(2)$. (Kenya).

72. The Kadhis' Courts Act, (1967) Cap. $11 \S 5$. (Kenya) ('A Kadhi's court shall have and exercise the following jurisdiction, namely the determination of questions of Muslim law relating to personal status, marriage, divorce or inheritance in proceedings in which all the parties profess the Muslim religion ....").

73. ICCPR, supra note 4, art. 26.

74. Id. arts. $9,14$.

75. Id. art. 23.

76. ICESCR, supra note 4.

77. African Charter, supra note 4.

78. Women's Convention, supra note 4. 
includes guarantees of protection against gender discrimination ${ }^{79}$ and a prompt and transparent adjudication of criminal charges. ${ }^{80}$ Its statutes clearly prohibit assault, ${ }^{81}$ which can include domestic assault, and protect rights of inheritance by widows and daughters. ${ }^{82}$ Amidst much fanfare, the Kenyan government in 2006 also enacted the Sexual Offences Act criminalizing rape and sexual harassment, ${ }^{83}$ and the attorney general promised an ambitious program of training for police and judges on the new law. ${ }^{84}$

\section{Kenya's Failure to Recognize and Enforce the "Rule of Law"}

Despite Kenya's substantial affirmations of justice, most Kenyans lack access to the rule of law. The discordance between formal guarantees of the rule of law and the human rights crisis on the ground in Kenya demonstrates that the only way rule of law is going to be established and maintained in Kenya is if there is first substantial political will to embrace and enforce human rights guarantees.

79. Constitution, Art. 82 (2001) (Kenya). However, this provision goes on to contradict the spirit of its broader language by excluding the anti-discrimination guarantee from applying in family law, succession cases, and instances where customary law applies, leading one commentator to conclude that "the result is that at no time are [Kenyan] women guaranteed protection from sex-based discrimination." Bonita Ayuko \& Tanja Chopra, Justice for the Poor \& Legal Resources Foundation Trust, The Illusion of Inclusion 27 (2008).

80. Constitution, Art. 83 (2001) (Kenya).

81. Penal Act, (2003) Cap. $63 \S 251$. (Kenya).

82. The Succession Act, (1981) Cap. $160 \S 35$. (Kenya). But see Penal Act, (2003) Cap. $63 \& 2$. (Kenya) (indicating limitations of The Succession Law, including a bar on widows being the sole administrators of their husbands' estates and allowing exemptions for certain communities, including Muslims, based on tradition).

83. The Sexual Offences Act, No. 3 (2006), §§ 3, 23. (Kenya).

84. U.S. Dep't of State, Country Report on Human Rights Practices: Kenya (Mar. 11, 2008), http://www.state.gov/g/drl/rls/hrrpt/2007/100487.htm. But see The Sexual Offences Act, No. 3 (2006), § 38. (Kenya) (containing a disturbing "poison pill" that may discourage full reporting: if a complaint is found to be false, the complainant is subject to punishment equal to that for the offense originally alleged. It appears that a great deal of faith in the judicial system is necessary for a victim to risk this kind of boomerang result by coming forward to file a complaint.). 


\section{The Struggle for Women's Rights}

Women in particular suffer from a lack of legal protection, as domestic violence, ${ }^{85}$ sexual assault, ${ }^{86}$ forced marriages,${ }^{87}$ land theft, ${ }^{88}$ and economic exploitation ${ }^{89}$ are all perpetrated against Kenyan women with near in punity. Female circumcision is prohibited by law, but remains a routine practice in many Kenyan communities. ${ }^{90}$ Women perform an estimated $80 \%$ of Kenya's agricultural work, but own only $5 \%$ of the land. ${ }^{91}$ After an extensive 2002 investigation, Human Rights Watch reported that in Kenya, "[women's] rights to own, inherit, manage, and dispose of property are under constant attack from customs, laws, and individuals... who believe that women cannot be trusted with or do not deserve property."

85. See Kristin Kalla \& Jonathan Cohen, Open Soc'y Inst., Ensuring Justice for Vulnerable Communities in Kenya: A Review of HIV and AIDSRelated Legal Services 22 (2007), http://www.soros.org/initiatives/ osiea/articles_publications/publications/kenya_20070416/kenya_20070416.pdf (citing breathtaking rates of domestic violence, including $94 \%$ of women in Nairobi reporting having experienced at least one episode of domestic violence in the previous year); see also IRINnews.org, Kenya: Sexual and Domestic Violence Prevalent (Oct. 27, 2005), http://www.irinnews.org/report.aspx?reportid=56856 (citing a demographic health survey carried out by the Ministry of Planning in 2003 that revealed that at least half of all Kenyan women had experienced violence since the age of 15 , with close family members among the perpetrators).

86. U.S. Dep't of State, supra note 84.

87. Tanja Chopra, Promoting Women's Rights By Indigenous Means: An Innovative Project in Kenya, Briefing Note (World Bank/Just. for the Poor 2007) July 2007, at 2, available at http://siteresources.worldbank.org/ INTJUSFORPOOR/Resources/J4PBriefingNoteIssueJuly.pdf.

88. Connie Ngondi-Houghton, UNDP, Comm'n on Legal Empowerment of the Poor, Access to Justice and the Rule of Law in Kenya 27-28 (2006), available at http://www.undp.org/LegalEmpowerment/reports/National\%20Consultation \%20Reports/Country\%20Files/15_Kenya/15_3_Access_to_Justice.pdf.

89. See World Bank, Justice for the Poor: Kenya (2008), http://worldbank.org/html/extdr/thematic.htm (follow "Law and Development" hyperlink; then follow "Justice for the Poor" hyperlink; then follow "Country Programs" hyperlink; then follow "Africa" hyperlink and finally the "Kenya" hyperlink) (discussing how under Kenya's law women have a right to inherit their fathers' and deceased husbands' land but "cultural, informational and institutional barriers" prevent the vindication of these rights, causing the increased marginalization of women while gender discrimination in the workforce causes women to earn less and work in inferior conditions).

90. Ayuko \& Chopra, supra note 79 , at 23.

91. Ngondi-Houghton, supra note 88 , at 27.

92. Janet Walsh, Human Rights Watch, Double Standards: Women's Property Rights Violations in Kenya 1 (2003) available at http://www.hrw.org/en/node/12352/section/8; cf. Social Watch, Gender Equity 
Leah J.'s case discussed at the beginning of this Article represents a disturbingly common phenomenon that occurs when a Kenyan widow, often left with young children after a husband succumbs to HIV/AIDS, either is forced to marry her brother-in-law or is driven off the land that would otherwise support her family. ${ }^{93}$ In Kenya, gender-based violence is disturbingly common, but successful prosecution of the crime is disturbingly rare. A hospital-based advocacy program in western Kenya that supports survivors of gender-based violence as they pursue criminal charges recently reported little success in several dozen cases. ${ }^{94}$ Even after advocates convinced police to waive their typical fees charged to persons wishing to file the report of a crime, women who had survived assault faced a cumbersome bureaucracy, the alleged perpetrators were allowed to recontact and intimidate them, and the women faced regular indifference from police and prosecutors throughout the process. ${ }^{95}$ A recent review of women's legal status in the pastoralist societies in Northern Kenya reported rampant domestic violence, but such pervasive police indifference to the crime that women said they had stopped bothering to report their assaults. ${ }^{96}$ The same study concluded that women's lack of access to basic legal protections "demonstrates that the inclusion of women through international conventions, domestic legal reform and gender quotas in participatory processes is illusory."

\section{The Struggle to Create a Fair Judicial System}

The Kenyan court system suffers from a number of systemic problems. The judiciary is plagued by undue influence from the executive branch ${ }^{98}$ and a reputation for overall corruption. ${ }^{99}$ Despite

Index: 2008 (2008) available at http:/www.socialwatch.org/sites/ default/files/GEI2008_eng.pdf (showing that unfortunately, gender equity is a significant challenge for most other modern nations as well, as recent global evaluations show that economic gender equity is elusive even in developed countries).

93. Chopra, supra note 87, at 2; see also Betty Potash, Widows in Africa, in Widows in African Societies 1, 17, 20 (1986) (discussing severely limited options available for widows in many Kenyan societies).

94. Report by Lucy Wanjiru of Centre for Assault Recovery, Eldoret, Kenya, January, 2009 (on file with author).

95. Id.

96. Ayuko \& Chopra, supra note 79, at 14.

97. Id. at 7 .

98. See Kim Matthews \& William H. Coogan, Kenya and the Rule of Law: The Perspective of Two Volunteers, 60 Me. L. Rev. 561, 568 (2008) (discussing the 
the Ministry of Justice's dismissal of twenty-three judges for corruption in $2003,{ }^{100}$ the African Union's African Peer Review Mechanism in 2006 still found "a visible lack of independence of the judiciary" in Kenya. ${ }^{101}$ Given that the President of Kenya has regularly wielded his power to transfer judges to unattractive outposts when he disapproves of their rulings, this was not surprising. ${ }^{102}$ Moreover, the judicial system is unable to redress a number of serious abuses. Kenyan police are notorious for shooting criminal suspects ${ }^{103}$ and shaking down citizens for petty bribes. ${ }^{104}$ The Kenyan National Commission on Human Rights estimated there were 700 extrajudicial killings by police in 2007 , and 13 Nairobi robbery suspects were shot and killed in one day alone. ${ }^{105}$ Police rarely are arrested or prosecuted for excessive use of force. ${ }^{106}$

predominance and long-standing history of the authoritarian president state in Kenya).

99. Id.; see also Transparency International, The Kenya Bribery Index 2007, at 18 (2007) (reviewing data from a survey that shows $92 \%$ of the judiciary's clients face bribery); see also Tanja Chopra, Justice for the Poor, Reconciling Society and the Judiciary in Northern Kenya 16 (2008) (explaining that a $21.3 \%$ rate of all bribes occurring in the judiciary during a 2006 survey has led to a general perception that bribery plays a key role in courts and one cannot expect justice without the necessary funds).

100. Marc Lacey, A Crackdown on Corruption in Kenya Snares Judges, N.Y. Times, October 26, 2003, at A4.

101. U.S. Dep't of State, supra note 84; see also Matthews \& Coogan, supra note 98 , at 570 (visiting U.S. attorney who attempted to practice in Nairobi in 2006 and 2007 pronounced the judiciary she encountered "plagued by corruption, improper influence and partiality.").

102. See Mary A. Ang'awa, A View From Kenya, Hum. Rts., Winter 2009, at 23 (where Kenyan High Court judge reports being transferred to distant outpost after supporting judicial independence reforms); see also Matthews, supra note 98 , at 568 (discussing how the executive dismissed nearly half the judiciary in an anti-corruption campaign, including the transfer of two judges to posts 200 kilometers away for ruling against the executive's interests).

103. See Amnesty International, Amnesty International Report 2009 Kenya, http://thereport.amnesty.org/en/regions/africa/kenya (last visited Oct. 14, 2009).

104. Joshua N. Auerbach, Police Accountability in Kenya, 3 Afr. Hum. Rts. L.J. 275, 277 (2003).

105. U.S. Dep't of State, supra note 84.

106. Auerbach, supra note 104, at 292. However, there have been some very recent uses of the civil court system by alleged victims of Kenyan police misconduct to pursue complaints of unlawful arrest and harassment. See Eunice Machuci, High Court Directs Over Case on Police Conduct, Daily Nation, July 7, 2009, available at http://allafrica.com/stories/200907070827.html; see also Frame of Suit Act, (1975) Cap. $21 \S 2$. (Kenya) (demonstrating that there exists the 
Indigent criminal defendants are not appointed counsel unless they are accused of a capital crime. ${ }^{107}$ But those few defendants who can afford counsel are often acquitted because the police, not attorneys, handle most of the court prosecution duties, ${ }^{108}$ leading to a potential sense of impunity for the few defendants with resources or connections allowing them to "beat" the dysfunctional criminal justice system. ${ }^{109}$ Kenya's prisons are violent, overcrowded, and the site of unchallenged police torture. ${ }^{110}$

The Kenyan court system also suffers from enormous case backlogs, ${ }^{111}$ with as many as one million cases pending in 2008 and 300,000 sitting before Nairobi's high court alone. ${ }^{112}$ The clogged court system means that many Kenyan criminal defendants wait in those prisons for years before receiving a trial. ${ }^{113}$ The civil courts are also generally off-limits to the poor, who cannot afford either filing fees ${ }^{114}$ or hired counsel. ${ }^{115}$ The financial bar to formal courts leaves most

potential under Kenyan law for such claims to be joined in a class action suit asking for broad remedies).

107. See Alloys Omondi Nanga v. Republic of Kenya, at 5 (C.A.K. Nov. 24, 2006), http://docs.thecourt.ca/top_court_talk/omondi.pdf (noting that although Kenyan law does not specifically require appointment of counsel to indigent defendants in any case, it is custom in Kenyan courts to appoint such counsel to defendants accused of murder).

108. Chopra, supra note 99 , at 15 .

109. Those who enjoy the freedom that comes with an ineffectual criminal justice system include government ministers. A poignant example in the early 1990 s, known as the Goldenberg scandal, involved government funds given for fictitious gold exports and cost Kenya as much as $10 \%$ of its gross domestic product. Investigations implicated government officials up to and including President Daniel arap Moi. Yet no top official has been convicted of any crime. See, e.g., Michaela Wong, It's Our Turn to Eat 322 (2009) ("The culprits are likely to spend the rest of their lives being driven around by chauffeurs, relaxing in Nairobi's wood-paneled clubs and strolling the lush fairways of its golf clubs.").

110. U.S. Dep't of State, supra note 84.

111. Id.

112. Comm'n on Legal Empowerment of the Poor, supra note 6, at 32.

113. Robert Winslow, Crime and Society - Kenya, http://www.rohan.sd su.edu/faculty/rwinslow/africa/kenya.html (last visited Oct. 9, 2009).

114. See Chopra, supra note 99 , at 12 (filing fees are usually about 700 Kenyan shillings, about $\$ 12$ U.S.) (explaining that filing fees of 700 Kenyan shillings, or about $\$ 12$ U.S., make it particularly difficult for poorer social groups to make use of the courts).

115. Kalla \& Cohen, supra note 85 , at 22,24 . It should be noted that the United States, whose judicial system is often held up as a model for developing countries to emulate, also largely fails to ensure counsel for the poor in civil legal matters, see, e.g., Debra Gardner, Justice Delayed Is, Once Again, Justice Denied: The Overdue Right To Counsel In Civil Cases, 37 U. Balt. L. Rev. 59, $70-71$ 
aggrieved parties with no alternative but the customary system, Islamic courts, or appeals to chiefs or elders. While these forums can often produce just results, cultural biases against the rights of women, for example, can make them an inadequate substitute for formal adjudication. ${ }^{116}$

\section{Corruption in the 2007 Election}

Beyond the justice system, broader evidence of a missing rule of law was provided by the 2007 Kenyan presidential election, which non-partisan domestic ${ }^{117}$ and international ${ }^{118}$ election observers concluded was stolen by the incumbent Mwai Kibaki. ${ }^{119}$ Widespread ethnic and political violence followed the announcement of the disputed result, and over 1,000 people were killed and 500,000

(2007) (arguing that the presence of counsel in civil cases is crucial to a fair outcome and is unattainable without substantial funds). The U.S. also has significant problems assuring competent counsel to indigent criminal defendants, see, e.g., Mary Sue Backus \& Paul Marcus, The Right to Counsel in Criminal Cases, A National Crisis, 57 Hastings L.J. 1031, 1034 (2006) (demonstrating how the system doesn't function well by offering examples of ineffective counsel as well as statistics that show poor people account for more than $80 \%$ of individuals prosecuted, that these criminal defendants plead guilty approximately $90 \%$ of the time, and of these cases, more than half the lawyers entered pleas for their clients without spending any significant time on the cases, without interviewing witnesses, or filing motions). Further, the U.S. is criticized for an over-politicized judiciary, see Upham supra note 54, at 32, and for adopting a post-September 11, 2001 "monarchical" presidential model.

116. See, e.g., Kenneth K. Mwenda et al., Property-Grabbing Under African Customary Law: Repugnant to Natural Justice, Equity, and Good Conscience, Yet A Troubling Reality, 37 Geo. Wash. Int'l L. Rev 949, 951-52 (2005) (“The Zambian legal system integrates both African and European legal procedures. While the Zambian Constitution declares gender discrimination illegal, it also holds an exception for matters usually handled by customary law."). But see Chopra, supra note 87, at 3 (reporting a successful attempt to change the tribal Luo culture by engaging community leaders); World Bank, supra note 89 (arguing that these forums can improve their respect for gender equity).

117. Kenyans for Peace and Truth with Justice, Kenyan Election Observers' Log, Dec. 29-30, 2007 (2008), available at ftp://ftp.wizzy.com/pub/wizzy/kenya/KPTJelectionobs.pdf.

118. See Jeffrey Gettleman, Disputed Vote Plunges Kenya Into Bloodshed, N.Y. Times, Dec. 31, 2007, at A1.

119. After the election, a joke which circulated in Kenya was based on the premise that the incumbent President and three others went into a room and all cast secret ballots to choose the next president, with the results to be tallied by the Election Commission appointed by the president. Who won this election, as the joke would have it? The incumbent president, by 11 votes. 
persons were internally displaced. ${ }^{120}$ As Kenyan High Court Judge Mary A. Ang'awa wrote, the lack of faith in the justice system played a large role in the descent into chaos:

When the results were announced, the losers felt cheated and were angry. When they were told, "If you are not satisfied with the election results, go to court and challenge them," they responded, "We have no confidence in the judiciary; we refuse to go to court."

As a judicial officer of twenty-seven years at that time, fourteen on the High Court of Kenya, this remark cut me to the core. Instead of organized and rational legal intervention, violence broke out and the country burned. ${ }^{121}$

Amnesty International, Human Rights Watch and other human rights organizations found significant evidence that much of the post-election violence was coordinated and supported by political actors, but no high-level leaders have been either arrested or prosecuted. ${ }^{122}$ The post-election violence followed a pattern of attack by one group and then retaliation by another, which is not an unfamiliar sequence in Kenya. ${ }^{123}$ Human rights observers blame this pattern of retribution, and the country's history of mob attacks and violence connected to land disputes and alleged criminal behavior, on a prevailing lack of confidence in the Kenyan criminal justice system's ability to bring perpetrators to justice. ${ }^{124}$ These ground-level conclusions are consistent with the findings by William Easterly that countries are at a greater risk of ethnic conflict if their governments

120. See Human Rights Watch, From Ballots to Bullets 24-35 (2008), available at http:/www.hrw.org/sites/default/files/reports/kenya0308web.pdf (a detailed account of the Kenyan 2007 election and post-election violence, and the involvement of political leaders in causing and stoking the turmoil).

121. Ang'awa, supra note 102, at 23 .

122. Human Rights Watch, supra note 120 , at 20.

123. Id. at $17-20,42-55$.

124. See U.S. Dep't of State, supra note 84. A recent survey showed that in rural Kenya, only $7 \%$ of the population says it reports disputes to the police, with the vast majority preferring instead to bring their complaints to chiefs, elders, or other informal venues. Chopra, supra note 99, at 11 ("People do not necessarily see the official system as the best place to sort out their grievances. One of the foremost reasons for this is that local communities have different ideas of what is 'just' and how conflicts ought to be resolved."). However, chiefs themselves are civil servants in Kenya and are empowered under law to maintain order in their jurisdictions. The Chiefs Authority Act, (1997) Cap. 128 § 6. (Kenya). 
cannot or do not enforce rule of law concepts like protection of minorities and property rights. ${ }^{125}$

\section{THE WIDESPREAD FAILURE OF EFFORTS TO DEVELOP RULE OF LAW}

As shown above, the international community has responded to the absence of rule of law and human rights in Kenya and other developing countries with significant investments in rule of law programming as part of an overall development approach. However, these rule of law efforts have been largely ineffective. This failure is the result of adherence to a misguided model of top-down efforts to impose rule of law on countries without adequate attention to the necessary task of growing grassroots-level political will for enforcement of basic human rights.

\section{A. The "Top-Down" Approach to Rule of Law Programming}

Rule of law programming has been largely designed as a "topdown" approach to achieving legal reform, with the focus of intervention on state institutions and the elites of the justice system. The World Bank Vice President has formally announced that since "judges are the key to an effective and efficient legal system, the Bank's activities concentrate on judicial training; judicial codes of conduct; evaluation and discipline; qualification, appointment and promotion of judges." 126 The practical application of this strategy is that rule of law spending largely revolves around intervention with the judiciary and other elite-level government actors. ${ }^{127}$ In development discussions, the term "law reform" is sometimes even literally equated with "judicial reform."128

The manifestation of this judiciary-centered approach is found in the significant expenditures on courthouse structures, equipment, judge training, and international judicial exchanges, with markedly smaller amounts set aside for grassroots interventions.

125. William Easterly, Can Institutions Resolve Ethnic Conflict? 16 (World Bank, Policy Research Working Paper Series No. 2482, 2000).

126. The World Bank, Legal and Judicial Reform, supra note 16 at 5.

127. See Daniels \& Trebilock, supra note 54, at 119; see also Carothers, supra note 56, at 8 (noting the focus on judiciaries in rule of law promotion); see Trubek, supra note 22, at 86 (arguing that rule of law projects place "special emphasis" on issues relating to the judiciary).

128. Carothers, supra note 56, at 8; see also Jensen, supra note 30 , at 345 (discussing a "standard package of judicial reforms" in rule of law initiatives). 
World Bank staff admits that part of the allure of investing in court buildings and equipment is that they are expensive, and therefore help achieve the bizarre-but-true priority for Bank personnel: ensure that money is spent. "Disbursements are a primary indicator of a project's progress," writes Linn Hammergren, senior public sector management specialist in the World Bank Latin America Regional Department, and as such, "[t]he task manager's main concern . . . is to keep the money flowing." ${ }^{29}$ For example, a nearly $\$ 70$ million law reform project in Guatemala, funded by the World Bank, USAID, and the European Union, among others, was dominated by court construction and judicial training. ${ }^{130}$ The Bank evaluated the results of its investment as "moderately unsatisfactory," using its official project completion report to candidly acknowledge the limited efficacy of money spent on buildings and seminars. The report stated:

Although so obvious as to hardly bear mention, without counterpart buy-in, a judicial or institutional reform effort will not get far. It is the corollary to this statement that is more important: buy-in means not just accepting the donor contributions, but rather internalizing and actively pursuing the change goals behind them. ${ }^{131}$

One explanation provided for the dominance of this exceedingly formal, elite-focused approach to law reform is that rule of law programs are largely designed by lawyers from the global North, who have been criticized for a lack of background in the field of development. ${ }^{132}$ It appears these lawyers have been comfortable with the strategy of implanting a global North-style legal system onto another culture, and have preferred to pursue that strategy via court construction projects and convening meetings and seminars with elite judicial officers and government leaders. ${ }^{133}$

129. Hammergren, supra note 55, at 314; see also Jensen, supra note 30, at 350-51 (multilateral development banks seek investments that can absorb large amounts of capital unconcerned with effectiveness of investments).

130. World Bank, Implementation and Completion Report on a Loan of U.S. \$33 Million to the Republic of Guatemala for a Judicial Reform Project 4-5 (2008). However, the report does note that USAID interventions in Guatemala, including 24-hour courts to address arrestee backlog, were successful. $I d$. at 43.

131. Id. at 42 .

132. See Samuels, supra note 26, at 21; see also Thomas J. McInerney, Law and Development as Democratic Practice, 38 Vand. J. Transact'l. L. 109, 117-18 (highlighting the fact that the high number of lawyers working in rule of law reform results in a focus on legal questions).

133. See generally Barron, supra note 48 , at 8 (listing insufficient knowledge of local culture, hostility to foreigners, and excessive costs as issues faced by foreign lawyers); Carothers, supra note 56, at 12-13 (discussing the 
Rule of law assistance strategies often include support for direct legal services and funding for civil society advocates for legal rights, usually bundled under the heading of "access to justice" programming. But those investments are characterized by critics like Erick Jensen as "lip service interventions [that] always find their way into donor reports, but they receive very little if any MDB [multilateral development bank] funding .... Activities related to access to justice for disadvantaged sectors-women, the poor, lower castes-are always a part of the standard package, but more often than not, the very last part."134 The World Bank appears poised to prove Jensen correct yet again in a forthcoming $2009 \$ 40$ million loan to Kenya, which the Bank and Kenya's Chief Justice report will be focused on judicial administration, training and computerization. ${ }^{135}$

\section{THE FAILURE OF RULE OF LAW PROGRAMMING}

Most observers have concluded that the recent decades' rule of law efforts have been largely ineffective in achieving either meaningful legal reform or significant economic development, ${ }^{136}$ and

major obstacles faced by foreign lawyers promoting rule of law in the last 30 years).

134. Jensen, supra note 30, at 350; see also Stephen Golub, Beyond Rule of Law Orthodoxy 5 (Carnegie Endowment for Int'l Peace, Democracy and Rule of Law Project, Carnegie Papers No. 41, 2003), available at http://www.carnegieendowment.org/files/wp41.pdf (explaining that, while banks undertake some innovative civil society initiatives, these often pale in comparison to the number of more orthodox initiatives); Jeremy Perelman, Beyond Common Knowledge: Empirical Approaches to the Rule of Law, 47 Harv. Int'l L.J. 531, 534 (2006) (book review) (arguing that rule of law practices remain unchanged despite attempts to focus on poverty eradiation).

135. World Bank, Strong World Bank Support for Anti-Corruption Efforts in Kenya (2008), www.worldbank.org (follow "Topics" hyperlink; follow "Law and Development" hyperlink; follow "News and Events" hyperlink; follow "News" hyperlink); see also Claire Wanja, Kenya Broadcasting Corporation, WB to Fund Establishment of Judicial Training Institute (Dec. 7, 2007), $\mathrm{http}: / / \mathrm{www} . \mathrm{kbc} . c 0 . k e /$ story.asp?ID=46934 (reporting that the institute is intended to "equip judicial officers with new and emerging branches of law and new methods of judicial adjudication").

136. See, e.g., Carothers, supra note 7, at 104-05 (arguing that the positive effects of rule of law have been exaggerated); Carothers, supra note 56 , at 8-9 (discussing the lack of knowledge on the essence of rule of law and how it develops); Brooks, supra note 51, at 2276-2340 (undermining the belief that rule of law decreases violence); Goodpaster, supra note 56, at 660 (arguing that legal reforms are "difficult to implement," corrupt, or unable to fully provide what they promise); Samuels, supra note 26, at 18 (arguing that less formal means are less 
the prevailing judiciary-centered approach has earned particular criticism:

A limiting and unsuccessful emphasis on "form" rather than "function" seems to have dominated much of the rule of law reform over the years. Programs have typically focused on institutional objectives and formal legal structures without a measured understanding of the political and economic dynamics that prevented such structures from existing in the first place .... The focus on formal institutions has largely resulted in shell-like institutions, unenforced and poorly understood legislation, and judges and police with little commitment to the rights and values sought to be entrenched through the reform. ${ }^{137}$

expensive and more efficient); Kaufman, supra note 54, at 10 (providing evidence that there is little progress worldwide in improving rule of law); Stephen Holmes, Can Foreign Aid Promote the Rule of Law?, 8 E. Eur. Const. Rev. 68, 69 (1999) (focusing on ineffective efforts to promote rule of law in the Russian Federation); McInerney, supra note 132, at 110 (research indicates that efforts to promote rule of law and good governance have not improved either). But see Hammergren, supra note 55, at 296-298, (defending the efficacy of some USAID rule of law programming). Unfortunately, in the area of development programming, rule of law efforts have plenty of company in the category of unproven interventions. Development assistance on the whole has its vociferous supporters, see Jeffrey Sachs, The End of Poverty (2005) (arguing that the US currently spends far too little on development assistance), and equally passionate detractors, see William Easterly, White Man's Burden (2006) (claiming that development assistance has traditionally been misguided and consistently failed to meet goals), but even many development scholars who see the value of development programming concede that decades of effort and billions of dollars in investment have had little proven success to date. See generally Paul Clements, Monitoring and Evaluation for Cost-Effectiveness in Development Management, $2 \mathrm{~J}$. MultiDisciplinary Evaluation 11, 11-24 (2005) (discussing the lack of accountability in development assistance); Paul Collier, The Bottom Billion (2007) (discussing broadly why international aid has not resulted in measurable improvement in developing nations).

137. Samuels, supra note 26, at 17-18; see also Carothers, supra note 56, at 8 (noting that "it is by no means clear that courts are the essence of a rule-oflaw system in a country ... . Y Yet for the last ten to fifteen years, rule-of-law programs have given dominant attention to judiciaries, without much examination of whether such a focus is really the right one."); Daniels \& Trebilock, supra note 54, at 119 (discussing the focus on formal policing as an aspect of rule of law); Golub, supra note 134, at 61 ("the concept of justice represents a broader and more effective organizing principle than the rule of law"); Maria Dakolias, Legal and Judicial Development: The Role of Civil Society in the Reform Process, 24 Fordham Int'l L.J. S26, S30 (2000-2001) (arguing that judicial reforms may only provide temporary solutions). 
Another commentator, Frank Upham, compared the topdown rule of law approach to the Soviet Union's failed economic model and bluntly pronounced the record of law reform as "dismal."138 Indeed, empirical evaluations of judiciary-centered reforms have not shown significant positive effects on availability or efficiency of justice. ${ }^{139}$ Analyses of rule of law efforts in Latin America have shown that most programs there have had neither indirect effects on economic development nor significant direct impact on the law as it applies to the people. ${ }^{140}$ The U.S. General Accounting Office concluded that the U.S.'s extensive rule of law investments in the former Soviet Union were largely ineffective, ${ }^{141}$ a conclusion also reached regarding rule of law efforts in Kosovo. ${ }^{142}$ Karen Bravo labeled the adoption of new laws, a new constitution, and the ratification of human rights treaties in Armenia-reforms generously supported by bilateral and multilateral aid and loans-as "smoke and mirrors" designed to hide corrupt elections and an increasingly autocratic system of government. ${ }^{143}$

A defining characteristic of this formalistic approach to rule of law programming is its reliance on "transplants" of legal systems characteristic of the global North into developing countries, despite the well-chronicled failure during the 1960s law and development era of this approach. ${ }^{144}$ Efforts to transplant a theoretically high-

138. See Upham, supra note 54 , at 6.

139. Jensen, supra note 30, at 358-59.

140. Prillaman, supra note 62, at 163-65; see also Linn Hammergren, UNDP, Fifteen Years of Judicial Reform in Latin America 7 (1999) ("TT]he traditional, institutionalized remedies-new laws, higher budgets, more courts, or massive judicial purges-have not worked any miracles and occasionally have made things worse.").

141. U.S. General Accounting Office, Former Soviet Union: U.S. Rule of Law Assistance Has Had Limited Impact and Sustainability (2001). See also Holmes, supra note 136, at 70 (explaining that the incoherent Russian state tenuously connected to a demoralized society is the reason for little rule of law despite foreign efforts to promote it); Bravo, supra note 115, at 489 (claiming that since 1991 rule of law reform in Armenia has been largely superficial and formalistic).

142. Brooks, supra note 51, at 2280, 2290-2301.

143. Bravo, supra note 115 , at $499,517$.

144. Trubek, supra note 22, at 84-86 (discussion of failed "transplant" strategy during law and development era); see also Daniel Berkowitz et al., Economic Development, Legality and the Transplant Effect, 47 Eur. Econ. Rev. $165,181-86$ (2003) (offering quantitative analysis showing significantly lower levels in indicators for rule of law in countries where unfamiliar law was transplanted compared to countries that adapted legal systems that more closely resembled customary law). The belief that the legal systems of the West could 
functioning legal system into new postcolonial countries were and are mistakes of both hubris ${ }^{145}$ and strategy. ${ }^{146}$ Thomas McInerney is among many observers who argue that the countries' own indigenous civil society leadership_-which in most cases helped lead the struggle for independence-needed to be supported in their own efforts to grow and apply their own systems of justice. "[I]nclusive and deliberate legal reform is the sine qua non for the creation of legitimate law and democracy," McInerney writes. ${ }^{147}$ "The democratic process itself is necessary to determine the content of rights." ${ }^{148}$

But rule of law funders have candidly admitted that their reform efforts have been regularly launched without the involvement of the non-elite public that the legal systems were designed to serve. ${ }^{149}$ Unsurprisingly, this top-down, ethnocentric approach to rule of law reform has not effectively engaged customary forms of dispute resolution by non-state actors like tribal councils, which are the forum for as much as $80 \%$ of cases in developing countries ${ }^{150}$ and are sometimes quite effective at resolving disputes. ${ }^{151}$

Economists like de Soto ${ }^{152}$ and Douglass North ${ }^{153}$ long ago identified the central role that the informal economy plays in the

and should be simply replicated in the developing world can trace its origins at least as far back as Montesquieu, who concluded that "the intelligent world also has its laws that by nature are invariable." Charles de Secondat Montesqieu, The Spirit of the Laws 4 (Anne Cohler ed., Cambridge Univ. Press 1989) (1750).

145. See supra note 115 for discussion of the many ways in which purportedly model legal systems like the American system fail to measure up to rule of law ideals.

146. See, e.g., Comm'n on Legal Empowerment of the Poor, supra note 6, at 3 ("Reforms that are imposed, no matter how well-intended, rarely take root in society. To be recognized as relevant and legitimate by a broad majority of people, laws must be anchored in existing values, customs and structures, and also be consistent with human rights obligations.").

147. McInerney, supra note 132, at 124 .

148. Id. at 127.

149. Linn Hammergen, USAID, Political Will, Constituency Building and Public Support for Rule of Law Programs 4 (1998).

150. Department for International Development, Safety, Security and Accessible Justice 58 (2002).

151. See Widner, supra note 64, at 66; see also Samuels, supra note 26, at 18-19 (arguing that tradition, informal procedures should be considered in rule of law programming because they are more effective and less costly). But see Mwenda et al., supra note 116, at 950 (finding that customary African law is often used to deprive widows from owning property); Ayuko \& Chopra, supra note 79 , at 40 (arguing that such forums can apply entrenched biases against the rights of women).

152. See de Soto, supra note 37 , at 153. 
lives of the world's poor. The formal approach to rule of law is not well-suited to address this critical sector. ${ }^{154}$

\section{THE ABSENCE OF POLITICAL WILl FOR LAW REFORM}

Rule of law scholarship reveals a remarkable degree of consensus that the recent decades' interventions have largely failed. This scholarship also contains a remarkable degree of consensus as to the reason for the failure. The concluding diagnosis has been the inability to achieve the "political will" that supports human rights, transparency, and the predictability of justice. United Nations leadership, ${ }^{155}$ Western law professors, ${ }^{156}$ African grassroots legal activists, ${ }^{157}$ economists, ${ }^{158}$ USAID, ${ }^{159}$ and the World Bank itself ${ }^{160}$ specifically identify political will as the chief barrier to achieving rule of law in developing countries. ${ }^{161}$ Even when the terminology varies, the conclusion is the same: The World Bank has conceded that social and political reform is needed to achieve law reforms, ${ }^{162}$ while some

153. See Douglass C. North, Institutions, Institutional Change and Economic Performance 67 (1990).

154. See Comm'n on Legal Empowerment of the Poor, supra note 6, at 17-19.

155. See Comm'n on Legal Empowerment of the Poor, supra note 60, at 5.

156. See, e.g., Goodpaster, supra note 56, at 688 (arguing that even a remarkable system-wide law reform achievement may do little to affect rule of law without political will to make it meaningful).

157. See Comm'n on Legal Empowerment of the Poor, supra note 60, at 6.

158. See de Soto, supra note 37, at 158-59 ("Implementing major legal change is a political responsibility . . . creating an integrated system is not about drafting laws and regulations that look good on paper but rather about designing norms that are rooted in people's beliefs and are thus more likely to be obeyed and enforced.").

159. See Hammergren, supra note 55, at 297.

160. See Barron, supra note 48 , at 29.

161. Hammergren argues that the ubiquitous references to political will in law reform discussions do not indicate an agreed-upon meaning for the term. See Hammergren, supra note 149, at 12 ("[Political will] is the slipperiest concept in the policy lexicon. It is the sine qua non of policy success which is never defined except by its absence."). I disagree. In the rule of law context, the term seems to be used in a fairly uniform context to mean the existence of empowered institutions or individuals, whether motivated by their own initiative or by outside pressure, committed to the principle that law restricts the state's autonomy and delivers a responsibility for transparency, accountability, and the protection of equity and human rights.

162. See, e.g., World Bank, Engendering Development 140-44 (2001) (arguing that legal reform alone cannot bring about true gender equality as social and political norms also have a drastic impact on the role of sexes in society). 
rule of law commentators refer to the need for "cultural change"163 or "deep societal changes," guarantees are more dependent on political factors than on legal ones. ${ }^{165}$

The widespread frustration over the inability to achieve political will for reform reveals the limitations of the legal and economic theories upon which law reform efforts are based. Carothers says, with substantial justification, that "rule of law proponents are short on knowledge on how rule of law develops in societies and how such development can be stimulated beyond simplistic efforts to copy institutional norms. ${ }^{\text {166 }}$ Carothers goes on to articulate more clearly the unknowns within the rule of law movement:

Clearly law is not just the sum of courts, legislatures, police, prosecutors, and other formal institutions with some direct connection to law. Law is also a normative system that resides in the minds of the citizens of a society.... Major questions abound, still unanswered. For example, how does the will to reform develop? Can it be generated and if so how? Should we assume that institutions change through gradualist reform processes willed by persons inside the system? Does public pressure play a major role? What about abrupt, drastic change provoked by persons outside the institutions who are dissatisfied with their function or who have their own goals about what institutions are to have? ${ }^{167}$

Carothers is undoubtedly correct that most rule of law promoters seem unaware of how these developments occur. But this does not mean that the questions he poses have not been studied and analyzed. In fact, the examination of how this kind of social and political change occurs is the very heart of the sociological study of

163. See, e.g., Dakolias, supra note 137, at S27 (stating that legal and judicial reform need time to take effect, as reform requires both a cultural change and a systemic change in the delivery of justice); Kleinfeld Belton, supra note 15, at 21 (noting that widespread institutional legal reform is not enough without cultural change, as recalcitrant cultures or balking politicians can undermine well organized rule of law institutions).

164. Samuels, supra note 26 , at 19.

165. See Viljoen \& Louw, supra note 66, at 32-33.

166. Thomas Carothers argues that anthropologists and sociologists, among others, have much to offer in the evaluation of how to influence rule of law norms. See Carothers, supra note 56, at 23-25.

167. Id. at $8,10$. 
social movements. The analysis of social movements would have predicted the failure of recent decades' top-down efforts to inculcate the political will for meaningful law reform. And social movement research provides guidance on how to pursue these important goals much more effectively going forward.

\section{GROWING POLITICAL WILL FOR LAW REFORM: APPLYING THE LESSONS OF SOCIAL MOVEMENTS}

\section{A. Introduction-A Social Movement Agenda}

Most scholarly analyses of rule of law efforts, and agencysponsored reporting of their shortcomings, run up against the barrier posed by the absence of political will for law reform, and then come to an exasperated halt. ${ }^{168}$ It is time to scale that barrier, and to do so by integrating lessons from the study of social movements to the process of designing effective methods to promote the rule of law and human rights.

For several decades, social scientists have analyzed the dynamics of social change, with a special emphasis on the movements that were able to achieve the change they sought. Studies of efforts like the U.S. civil rights movement of the mid-twentieth century, ${ }^{169}$ the Indian independence movement, ${ }^{170}$ the South African anti-apartheid movement, ${ }^{171}$ democracy movements in Russia ${ }^{172}$ and

168. See, e.g., Brooks, supra note 51, at 2326 (noting, as Carothers does, that anthropologists, sociologists and others have much to offer in the evaluation of how to influence rule of law norms).

169. See, e.g., Lewis M. Killian, Organization, Rationality and Spontaneity in the Civil Rights Movement, 49 Am. Soc. Rev. 770, 782 (1984) ("It is concluded that while organization and planning are key variables, social movement theory must take into account spontaneity and emergence, and the transformation of pre-existing structures.").

170. See, e.g., Charles Tilly, Social Movements, 1768-2004, at 90-92 (2004) (discussing the nationalistic Indian social movements against British rule led by Mohandas Gandhi).

171. See, e.g., Håkan Thörn, Anti-Apartheid and the Emergence of a Global Civil Society (2006) (analyzing the anti-apartheid movement from a comparative, historical and sociological perspective while highlighting the role of media and civil society in the context of the movement).

172. See, e.g., Elena Zdravomyslova, Opportunities and Framing in the Transition to Democracy: The Case for Russia, in Comparative Perspectives on Social Movements 122, 122-37 (Doug McAdam et al. eds., 1996) (analyzing symbolic framing in Russia to show changes in political opportunities over a transitional period). 
Eastern Europe, ${ }^{173}$ and the women's empowerment movement in Chile $^{174}$ have revealed the existence of what social movement theorists Doug McAdam, Sidney Tarrow and Charles Tilly call a "classical social movement agenda" that includes:

- Political opportunities for challengers to engage in successful collective action;

- Forms of organization allowing mobilization;

- Framing of grievances to dignify claims, connect them to other claims, and help produce a collective identity among claimants; and

- Repertoires of contention, or the means by which people engage in collective action. ${ }^{175}$

This Article employs these four components of the classical social movement agenda as the structure to assess the overall climate for growing political will in support of rule of law. Of course, it is impossible to review every developing country for its readiness to serve as a host of a rule of law movement, and there is no one-sizefits-all blueprint for such a movement. But this discussion reveals both the current opportunity for dramatic change and a clear path to guide rule of law promoters toward a more effective approach.

The components of a social movement agenda reflect the resolution of a long-standing debate among social movement scholars over the relative importance of the psychological state of movement actors vis-à-vis structural conditions inside and outside the movement. The "classical collective behavior" theory, which held that social movements come about because of spontaneous behavior of aggrieved parties responding to increased discontent, was the dominant U.S. perspective until the 1970 s. ${ }^{176}$ Then, the "resource

173. See, e.g., John K. Glenn, III, Framing Democracy (2001) (offering a critique of existing theories of democracy by explaining different paths of democracy within Eastern Europe).

174. See, e.g., Rita K. Noonan, Women Against the State: Political Opportunities and Collective Action Forces in Chile's Transition to Democracy, 10 Soc. F. 81, 94 (1995) (discussing the use of "mother's centers" under the Allende government in the early 1970 s that gave women a core of material and ideological resources, creating a collective action frame for subsequent mobilizations).

175. Doug McAdam et al., Dynamics of Contention 41 (2001).

176. See, e.g., Ted Robert Gurr, Why Men Rebel 234, 277 (1970) (likelihood of collective violence depends on the extent to which societies rely on coercion to maintain order, and is less likely to occur when discontented people have constructive means to achieve their goals). 
mobilization" theory, holding that social movements derive from more rational and strategic action constrained by external societal forces like governments or elites, proved to be more robust under quantitative analysis. ${ }^{177}$

Now, the most credible observers of social movements find a combination of these psychological and structural factors to be present in movement genesis. For example, Lewis Killian, in his study of the Tallahassee, Florida civil rights movement, found that key roles were played by both impromptu passionate marches and existing student, church, and NAACP (National Association for the Advancement of Colored People) organizations. Killian concluded:

New developments in theory have reminded us that organization, resources and planning are essential to the success of a social movement and should not be neglected in practice or research.... [But] social movement theory must take into account spontaneity and emergence and the forces which generate them. ${ }^{178}$

In recognition of the fact that political scientists and historians engage in their own analyses of the forces that cause societal changes, McAdam, Tarrow, and Tilly have begun the process of a broad theory synthesis by connecting the segregated studies of social movements, revolutions, democratization, and other such phenomena into an inclusive area of study they call "contentious politics."

The important lesson that social movement studies provide for rule of law promoters is that there are clear differences between the structures of movements that have successfully created the "political will" for change and their own failed efforts to establish support for rule of law and human rights in developing countries. And it is not too late to change course and achieve significant results

177. See John McCarthy \& Mayer Zald, Resource Mobilization and Social Movements: A Partial Theory, 82 Am. J. Soc. 1212, 1213 (1977); see also Jo Freeman, Resource Mobilization and Strategy: A Model for Analyzing Social Movement Organization Actions, in The Dynamics of Social Movements 167, 16789 (John McCarthy \& Mayer Zald eds., 1979) (a movement's success rate depends on the boundaries within which a movement's strategy develops, the resources a movement can mobilize, the limits on the use of these resources, and the environment that molds the possibilities for effective action).

178. Killian, supra note 169 , at 782.

179. See McAdam et al., supra note 175 , at 5 ("By contentious politics we mean: episodic, public, collective interaction among makers of claims . . . when (a) at least one government is a claimant, an object of claims, or a party to the claims and (b) the claims would, if realized, affect the interests of at least one of the claimants."). 
for the benefit of Leah J. and others similarly situated. With respect to rule of law and human rights, the core elements of the classical social movement agenda appear to exist in much of the developing world right now, including the settings that have proven to be the most inhospitable to prevailing top-down methods to promote rule of law. A significant historical opportunity for real reform is at hand, especially if rule of law promoters can re-orient their approach to support the grassroots advocates who can deliver the political will that has proven so elusive to date.

B. Political Opportunities for Challengers to Engage in Successful Collective Action

\section{An Atmosphere Ripe For Change}

In analyzing the first element of the classical social movement agenda, it is clear that external factors like population growth, governmental policies, funding availability, and the presence or absence of elite allies impact political opportunity, and thus the formation and relative success of social movements. ${ }^{180}$ But, to some extent, movement actors can also create their own political opportunity by "framing"-a process which will be discussed in more detail below-the current moment as ripe for dramatic action for law reform and human rights, i.e. "right here, right now, we have a chance to make history." order to endure, but there is evidence to support that rhetoric of opportunity in many parts of the early twenty-first century developing world.

The nations in question are, for the most part, young democracies that may be poised to follow the rights development trends of more mature democracies, most of which have seen

180. See, e.g., David S. Meyer \& Debra C. Minkoff, Conceptualizing Political Opportunity, 82 Soc. Forces 1457, 1476-80 (2004) (demonstrating that issue-specific and general political conditions are relevant predictors of social movement organization founding rates and that a movement's success depends on legislative developments and elite support for the movement's objectives).

181. William A. Gamson \& David S. Meyer, Framing Political Opportunity, in Comparative Perspectives on Social Movements, supra note 172, at 275, 276; see also Charles Kurzman, Structural Opportunity and Perceived Opportunity in Social Movement Theory: The Iranian Revolution of 1979, 61 Am. Soc. Rev. 153, 154-56 (1996) (Iranians assessed a positive opportunity for protest based on the strength of the opposition movement, rather than on a perceived structural weakness of the state). 
successful struggles for property rights, the rights of women and marginalized minorities, overcoming barriers like official corruption. ${ }^{182}$ De Soto in particular draws parallels between the struggle for property rights in the current developing world and the fits and starts of the nineteenth century progress toward defining similar rights in the United States. ${ }^{183}$ Social scientists at least as far back as Gunnar Myrdal ${ }^{184}$ and T.H. Marshall ${ }^{185}$ in the mid-twentieth century identified trends, if not universal patterns, of rights evolution in democratic societies. Evidence to support the notion of an increasing receptivity to the rule of law in developing nations comes from data showing a recent surge in the use of courts in Botswana, Uganda, and Tanzania, and a corresponding willingness of heads of state in those countries to grant increased autonomy to the judiciaries. ${ }^{186}$ These examples are significant, given the historical tendency of people in developing countries to mistrust the impartiality and effectiveness of the formal judicial system. ${ }^{187}$

\section{SELF-IMPOSED EXPECTATIONS BY LOCAL ELITES}

The trend of an increasing expectation of justice is also consistent with social movement research findings that government

182. See, e.g., Bravo, supra note 115 , at 579-580 (arguing that democratic transition in Armenia will be strengthened by organic domestic developments, similar to the way American democracy emerged from a period of darkness to increased personal rights through fundamental Constitutional amendments). For purposes of this social movement discussion, I am referring to countries not immediately emerging from conflict. However, it should be noted that those countries, although likely less ripe in terms of organizations ready to assume the call for reform, are also existing in moments of civic fluidity providing political opportunity for change. For a review of lessons drawn from rule of law programs in post-conflict and fragile countries, see Samuels, supra note 26, at 15-23.

183. De Soto, supra note 37, at 105-51.

184. Gunnar Myrdal, An American Dilemma: The Negro Problem and Modern Democracy 998-1004 (1944).

185. Thomas H. Marshall, Citizenship and Social Class and Other Essays 10-14 (1950). But see Guillermo O'Donnell, Reflections on Contemporary South American Democracies, 33 J. Latin Am. Stud. 599, 603-04 (arguing that the Marshall pattern of rights development from civil and political rights into social rights has not occurred in most of South America).

186. See Widner, supra note 64 , at 72-73.

187. See Kleinfeld Belton, supra note 15, at 10; see also Comm'n on Legal Empowerment of the Poor, supra note 60, at 34 (explaining that the majority of people see the judicial system as a viable means for solving disputes); see also Bravo, supra note 115, at 561 (noting that Armenians respond to corruption in government by general disregard of the rule of law). 
support for reform, even if it is a non-binding expression of support, will increase the opportunities for a social movement demanding that the government's rhetoric of reform be matched by its actions. ${ }^{188}$ As noted in Parts II and III above, there is no shortage of official recognition of the value of rights protection in developing countries, expressed in treaty signings and favorable language in constitutions and statutes. ${ }^{189}$ Although the rhetoric has little or no immediate effect in the legal protections available to citizens like Leah J., social movement research suggests the near-empty promises may raise popular expectations of justice, which in turn increase the prospects for long-term reform. ${ }^{190}$ Leaders who claim the mantle of human rights may soon be called upon by their citizens to practice what they preach.

\section{TRANSNATIONAL SUPPORT}

Further evidence of political opportunity for rights and law advocacy comes in the guise of transnational civil society actors, who now play a larger role in human rights promotion across the globe than at any time in history. ${ }^{191}$ In social movement parlance, groups such as these whose goals are to help individuals outside their own direct membership are known as "universalistic"192 advocates. The dramatic expansion of electronic communication enhances the connection that universalistic actors like Human Rights Watch and

188. See Meyer \& Minkoff, supra note 180 , at 1475 ; see also J. Craig Jenkins \& Charles Perrow, Insurgency of the Powerless: Farm Worker Movements (1946-1972), 42 Am. Soc. Rev. 249, 265 (1977) (arguing that there is a positive correlation between federal government actions and increased social movement influence).

189. For discussions of motivation for country leaders signing such treaties in the first place, see, e.g., Stephen Krasner, Sovereignty 121-23 (1999) (demonstrating that motives vary depending on the particular country and historical context and that the range of motives include desire to constrain future governments, to present the appearance of modernity, or to attract supporters in other countries); Eric Posner, Op-Ed., What the Cold War Taught Us: Liberal Democracies, Not Activists And International Law, Protect Human Rights, Wall. St. J., Apr. 22, 2007, at A9 (demonstrating that as populations become wealthier and more educated, they demand greater civil and political rights).

190. Meyer \& Minkoff, supra note 180, at 1462-63, 1469-70, 1474-75.

191. See Julie Mertus, From Legal Transplants to Transformative Justice: Human Rights and the Promise of Transnational Civil Society, 14 Am. U. Int'l L. Rev. 1335, 1336 (1999); see also McCarthy \& Zald, supra note 177, at 1225 (technological capacity recognized as a key resource for social movements well before internet technology was widely available).

192. William A. Gamson, The Strategy of Social Protest 55 (1990). 
Amnesty International can have with the developing world. The flow of information goes both ways: the transnational advocates share information about successful rights advocacy with the aggrieved in the developing world, and indigenous rights advocates relay back the details of their plight to the universalistic advocates who can lend their help to the cause. ${ }^{193}$ One key capacity offered by transnational civil society actors is attracting media attention, which can play a vital role in forming and mobilizing a social movement. ${ }^{194}$ The global movement against apartheid in South Africa provides a notable recent example of an effective transnational-local advocacy partnership. ${ }^{195}$ A lesser-known precedent can be found in Chilean legal advocates' documentation of human rights abuses during the $1970 \mathrm{~s}$ and 1980s. The information compiled by indigenous advocates was used by transnational human rights groups to pressure the Chilean government and obtain consistent United Nations condemnation of the government's human rights record. ${ }^{196}$

In comparing successful social movements to the recent clumsy efforts to instill rule of law, the most fundamental contrast is found in the role of the elite. As discussed above, the strategies of multilateral and bilateral investors in the rule of law have concentrated on direct attempts to try to win the hearts and minds of the judicial and political elite. Given that the current systems' dysfunctional nature provides substantial benefits to those very elites, more than one commentator has pointed out this strategy is unlikely to succeed. ${ }^{197}$ Ironically, even though a key component of political opportunity for rule of law movements is the existence of sympathetic, motivated and deep-pocketed funders like the World

193. Noam Cohen, Twitter on the Barricades, N.Y. Times, June 20, 2009, at WK4 (discussing the role of Twitter in disseminating information and organizing mass protests in Iran and Moldova).

194. Meyer \& Minkoff, supra note 180, at 1478.

195. See, e.g., Thörn, supra note 171, at 48-72 (discussing the globalization of the anti-apartheid movement, and the significant role that national policy, national organizations, and national political cultures played in shaping the antiapartheid struggle in different parts of the world).

196. Hugo Fruhling, From Dictatorship to Democracy, in Many Roads to Justice 55, 61-81 (Mary McClymont \& Stephen Golub eds., 2000).

197. See Kleinfeld Belton, supra note 15, at 9; see also Daniels \& Trebilock, supra note 54, at 129-130 (explaining the reluctance of high level officials to give up their power and thereby the status quo is unlikely to change); Carothers, supra note 56, at 8-9 (criticizing the focus on developing institutions, particularly the judiciary, rather than instilling a respect for law amongst the citizenry). The ill-fated "law and development" movement of the 1960 s also focused on the training of lawyers and judges. See Barron, supra note 48 , at 6 . 
Bank, investors' pay limited attention to indigenous service providers and movement actors. ${ }^{198}$

Even though institutions such as the World Bank and USAID are clearly elites themselves, and non-indigenous elites at that, there is substantial precedent for them to play key roles in successful social movements. The Indian independence movement, ${ }^{199}$ the South African anti-apartheid movement ${ }^{200}$ and the U.S. farm worker movement, ${ }^{201}$ among many others, were all supported financially by elite individuals and organizations.

In assessing the potential value provided by outside supporters of social movements, the work of Craig Jenkins and Charles Perrow on U.S. farm worker movements is particularly instructive. In comparing the failed 1946-1952 attempt by the national Farm Labor Union to organize farm workers with the successful effort by the United Farm Workers in 1965-1972, Jenkins and Perrow found no difference in the levels of farm worker discontent, the talents and dedication of the organizers, or the methods of contention. The difference between success and failure, they concluded, was the support of outside "liberal" groups like church organizations and organized labor, which was far more substantial for the later movement. The reaction of political elites was also less hostile to the second effort. Jenkins and Perrow conclude this scenario was not just fortuitous for the second movement, it was a prerequisite for its success: "[f]or a successful outcome, movements by the 'powerless' require strong and sustained outside support." 202

198. As Rosa Brooks notes, it is inherently arrogant for rule of law funders to try to "improve" other cultures considered to be deficient in the areas of justice and rights. Brooks, supra note 51, at 2339. Brooks correctly concludes that this kind of intervention, and a growing consensus on law and rights norms, is an unavoidable product of the globally interrelated nature of $21^{\text {st }}$ century society, not to mention the international agreements codifying these norms. $I d$. at 2334 . Of course, this "arrogance" by more developed nations offers its own political opportunities for indigenous law reform actors wishing to promote some aspects of global North legal norms.

199. David Arnold, Gandhi 92 (2001) ("One cannot but be struck by the extent to which India's saintly Mahatma and foremost peasant leader was bankrolled by the capitalist class.").

200. See, e.g., Thörn, supra note 171, at 31-33, 67 (describing how the antiapartheid movement and the Black Consciousness Movement were supported by elite individuals and international organizations).

201. Jenkins \& Perrow, supra note 188, at 266.

202. Id. at 251. 
The most obvious support which rule of law proponents can provide indigenous rights advocates and service providers is financial and technical assistance on reform advocacy, in keeping with the tradition of social movements obtaining such resources from outside individuals and organizations. International financial support may be the only option for advocates challenging the status quo from within their own countries, since they are by their contentious actions disqualifying themselves from much of the possible funding from their own government or country elites. ${ }^{203}$ Support from the development agencies is also consistent with an existing, if vastly under-utilized, component of these agencies' "access to justice" efforts. Although the World Bank organizations are prohibited by their Articles of Agreement from interfering in the political affairs of the countries they serve, ${ }^{204}$ there is precedent, albeit poorly funded precedent, for Bank efforts to establish human rights, empower women and minorities, and tackle governmental corruption. ${ }^{205}$ In fact, the World Bank's “Justice for the Poor" program, based in seven countries in East Asia and Africa, nurtures and supports local initiatives working toward what the Bank itself calls "pro-poor" justice reform. ${ }^{206}$ And USAID officials have reported that integration of non-governmental organizations into their rule of law planning efforts has caused the agency to devote increased attention and support to human rights, legal services, advocacy, and civil society actors. $^{207}$

\section{A. Organizations and Networks Prepared for Mobilization}

Social movements are built on a foundation of organizers, movement organizations, and networks of communication among movement actors. Historical accounts of social movements usually wind their way back to critical early action by organizers, with notable examples including the U.S. student anti-war movement of

203. See Golub, supra note 134, at 21.

204. Articles of Agreement of the International Development Association art. V, § 6, Jan. 26, 1960, 11 U.S.T. 2284, 439 U.N.T.S. 249.

205. See Golub, supra note 134, at 24; see also Hammergren, supra note 55, at 299 (discussing how the World Bank is increasing its involvement with civil society actors).

206. World Bank, Justice for the Poor, http://www.worldbank.org/justice forthepoor (last visited Oct. 12, 2009).

207. Hammergren, supra note 55, at 311 . 
the $1960 \mathrm{~s}^{208}$ and the Muslim Pashtun movement ${ }^{209}$ and Indian independence movement of the early and mid-twentieth century. ${ }^{210}$ For example, the Montgomery, Alabama bus boycott of 1955 and 1956, a landmark development in the U.S. civil rights movement, was originally organized not by Dr. Martin Luther King, Jr. or other ministers who subsequently became the movement's spokespersons, but by the lesser known E.D. Nixon, president of the Montgomery, Alabama NAACP, and Jo Ann Robinson of the local Women's Political Council. ${ }^{211}$ Within the civil rights movement, successful organizers included those who came from within the ranks of the local aggrieved, like Nixon and Robinson, as well as external civil rights activists, such as the students from Northern states who were the principal organizers in many Mississippi locations. ${ }^{212}$ To build the movements, these organizers tapped into existing organizations like the NAACP and African American churches and created new networks of communication among movement actors.

Such networks are crucial. Scholars have concluded that the ability of social movements to grow and recruit new members is directly related to the extent to which the movements are linked to other groups. ${ }^{213}$ For example, the timing of the U.S. women's liberation movement of the mid-1960s was dependent chiefly upon the creation of new networks of communication among women who had shared un-networked grievances for decades. ${ }^{214}$

1. Examples of Organizations Prepared for Mobilization

The nodes of connectivity for those rule of law networks are present in the wide variety of grassroots rights advocacy organizations that currently exist throughout the developing world.

208. Jo Freeman, On the Origins of Social Movements, in Waves of Protest 7, 12-14 (Jo Freeman \& Victoria Johnson eds., 1999)

209. Mohammad Raqib, The Muslim Pashtun Movement of the North-West Frontier of India: 1930-1934, in Waging Nonviolent Struggle 113, 113-134 (Gene Sharp ed., 2005).

210. Tilly, supra note 170 , at 90-92.

211. Killian, supra note 169 , at 772 ; see also Taylor Branch, Parting the Waters 129-136 (1988) (explaining the critical role played by E.D. Nixon and Jo Ann Robinson in Montgomery).

212. Charles M. Payne, I've Got the Light of Freedom 132-33 (1995).

213. David A. Snow, et al., Social Movements: A Micro-Structural Approach to Differential Recruitment, 45 Am. Soc. Rev. 787, 797-98 (1980).

214. Freeman, supra note 208, at 11. 
In Leah J.'s home country of Kenya, a recent conference on legal empowerment for the poor included civil society groups devoted to land reform, women's empowerment, children's advocacy, and HIV support. $^{215}$ The Law Society of Kenya has mobilized lawyers to advocate for human rights and provide direct legal assistance to the poor ${ }^{216}$ a network of community-based groups in the Malindi district have successfully organized to win concessions on access to water, ${ }^{217}$ and women's groups have formed to provide civic legal education and rescue girls from early marriages. ${ }^{218}$ This is not a new phenomenon in Kenya. In the waning days of colonialism, there were many examples of African civil society actors creating political will for dramatic change. One example is the Kikuyu Central Association, an early twentieth century advocacy organization focused on land issues, which was led by a young Jomo Kenyatta, who later helped lead the Kenya African Union (KAU). The KAU joined with other organizations like the East African Trades Union Congress in the campaign that would eventually lead to independence from Britain and Kenyatta's installation as Kenya's first president. ${ }^{219}$

Throughout Africa, there is a thriving civil society devoted to human rights advocacy at a local level, including community-based legal advocacy efforts in Somalia, ${ }^{220}$ South Africa, ${ }^{221}$ Liberia, ${ }^{222}$ Malawi, ${ }^{223}$ Burkina Faso, ${ }^{224}$ Ghana, ${ }^{225}$ Togo, ${ }^{226}$ Sierra Leone, ${ }^{227}$ and

215. Comm'n on Legal Empowerment of the Poor, supra note 60, at 1-2.

216. Daniels \& Trebilock, supra note 54, at 126.

217. Lucie E. White, African Lawyers Harness Human Rights To Face Down Global Poverty, 60 Me. L. Rev. 165, 168 (2008).

218. Ayuko \& Chopra, supra note 79, at 37 .

219. Martin Meredith, The Fate of Africa 80-90 (2005).

220. See, e.g., Samuels, supra note 26, at 30 (discussing the communitybased advocacy programs in Somalia).

221. See, e.g., Kalla \& Cohen, supra note 85 , at 28 (highlighting the different strategies used by the government of South Africa to bring legal services to the poor).

222. See, e.g., Achievements in Building and Maintaining the Rule of Law: MSI's Studies in LAC, E\&E, AFR and ANE, Occasional Paper Series (USAID/Office of Democracy and Governance, Wash., D.C.), Nov. 2002, at 131, available at http://www.usaid.gov/our_work/democracy_and_governance/ publications/pdfs/pnacr220.pdf (recounting the history of Liberia since its founding in 1821 and summarizing recent post-conflict developments in efforts to establish and support the rule of law).

223. See, e.g., id. at 133-34 (describing challenges to the development of democratic institutions in Malawi, and summarizing the contributions of USAID and other entities in strengthening the judicial system, rights education, and democratic institutions).

224. See, e.g., Daniel Manning, World Bank, The Role of Legal Services 
other locations. Grassroots organizations are poised to play critical roles in law reform advocacy throughout Latin America, reports Maria Dakiolas, where "[t]hey are particularly effective in drawing attention to issues or groups that may otherwise be overlooked or whose political voice is the weakest. Women, ethnic minorities, and other groups who do not always enjoy equitable representation in formal institutions often form NGOs [non-governmental organizations] in order to make their voices heard."228 Dakolias provides a broad discussion of how these Latin American reform organizations network in classic social movement fashion. ${ }^{229}$

2. Civil Society Actors in Ideal Positions to Effect Law Reform

A key advantage that such indigenous grassroots advocates possess over "top-down" law reform actors is their demonstrated ability to work in both formal and customary legal forums, the latter of which presents an area of clear weakness for current rule of law interventions. ${ }^{230}$ These civil society actors have shown a willingness to use paralegals and community advocates in addition to licensed attorneys in direct representation, and have engaged effectively with community leaders who often take the place of formal judges in dispute resolution. ${ }^{231}$ For example, in 2004, legal advocates in

Organizations in Attacking Poverty 50 (1999), available at http://siteresources.worldbank.org/EXTAFRREGTOPGENDER/Resources/RoleLe gal_en.pdf (describing the role of the Association of Women Jurists in establishing literacy and legal training programs in Burkina Faso).

225. See, e.g., White, supra note 217 , at 168-69 (describing the Ghana Legal Resource Center's successful use of community organizing techniques and litigation to persuade the Ghanaian government to back away from its system of "cash and carry" health policy).

226. See, e.g., Manning, supra note 224, at 51 ("[T]he World Bank has provided grants for institutional reform projects in Mali and Togo which, among other things, support legal literacy and legal aid program[s].").

227. See, e.g., Vivek Maru, Between Law and Society: Paralegals and the Provision of Justice Services in Sierra Leone and Worldwide, 31 Yale J. Int'l L. 427 (2006) (arguing that paralegals in Sierra Leone offer valuable legal services, including legal education and legal representation with a focus on concrete solutions while employing not only legal tools but also the more flexible tools of a social movement).

228. Dakolias, supra note 137, at S48.

229. Id. at S49-S52.

230. See Samuels, supra note 26, at 18-19.

231. See Kalla \& Cohen, supra note 85, at 29 (noting that paralegals provide an important source of legal assistance in Kenya by creating awareness 
western Kenya responded to the problem of women being denied their rights to inheritance by facilitating discussions among Luo ethnic group elders about their community's values in regard to women's well-being. Advocates discovered that the elders actually held a great deal of pride in a community self-image of supporting and protecting women. When confronted by advocates with evidence that the treatment of many Luo widows did not meet that standard, the elders changed the tribal practice to install women as trustees of the land after their husbands' death, thus guaranteeing a woman's right to remain on the family property. ${ }^{232}$

Referencing this kind of legal advocacy success by civil society actors, Stephen Golub has called for a switch in the rule of law paradigm away from a focus on state institutions and elites and toward "legal empowerment," the use of legal services, and other development activities that are "grounded in grassroots needs but can translate that community-level work into impact on national laws and institutions."233

As Golub notes, indigenous organizations working on legal issues have potential value and impact beyond rule of law or even human rights concerns. The World Bank, USAID and other rule of law actors have noted repeatedly that strong civil society organizations help alleviate poverty and broadly empower the citizenry, ${ }^{234}$ and Ernest Gellner and other commentators see the

of human rights and providing referrals to appropriate services); see also Samuels, supra note 26 , at 18 (stating that informal, traditional justice systems often exist even when formal frameworks have failed).

232. Chopra, supra note 87 , at 2-3.

233. Golub, supra note 134, at 103; see also Stephen Golub, Make Justice the Organizing Principle of the Rule of Law Field, 1 Hague J. on Rule L. 61, 6166 (2009), available at http://journals.cambridge.org/action/displayFulltext?type= $1 \&$ fid=4614144\&jid=ROL\&volumeId=1\&issueId=01\&aid=4614140 (arguing that the concept of broadly defined "justice," including social and economic rights, should replace the rule of law as the focus of international development agencies).

234. See, e.g., Civil Society Team, World Bank, World Bank-Civil Society Engagement: Review of Fiscal Years 2002-2004, at ix (2005), available at http://siteresources.worldbank.org/CSO/Resources/World_Bank_Civil_Society_Pro gress_Report_2002-2004.pdf (finding that a strong relationship between a civil society and the World Bank can improve development results); USAID, Why Civil Society Matters for Democracy, http://www.usaid.gov/our_work/democracy _and_governance/technical_areas/civil_society/ (noting that civil society can "transform" non-democratic countries and encourage reconciliation in postconflict situations). 
existence of a vibrant civil society of advocates as a precondition to democracy itself. ${ }^{235}$

One obvious role for rule of law funders is to support these groups in forging the networks that will enable them to fully realize their potential for making a positive impact on their communities. Successful models for that kind of networking support already exist: Bangladeshi human rights advocates found their influence increased after an external law reform funder, The Ford Foundation, enabled them to band together to share information and strategies. ${ }^{236}$ Similarly, Alternative Law Groups (ALGs) in the Philippines have created a network of over twenty small organizations working on legal empowerment issues such as land reform, labor issues, and the laws regarding rape and assault. ${ }^{237}$

\section{Conclusion}

Social movement outcome research, including Aldon Morris's powerful analysis of the 1960 African American sit-in movement (a pivotal development in the U.S. civil rights struggle), ${ }^{238}$ shows that the relative strength of these organizations, as measured in terms of size, network ties, internal organization and fundraising ability, will ultimately determine the success of the rule of law movement. ${ }^{239}$ Properly supported, existing and evolving law reform groups and their leaders are poised to play the pivotal roles that social movement historians, ${ }^{240}$ along with iconic movement organizers like Saul Alinsky, ${ }^{241}$ have long predicted. As Kirsti Samuels notes in discussing the future of the efforts to instill rule of law, "Domestic political reform pressure and local political reform champions are

235. Ernest Gellner, Conditions of Liberty 184-89 (1994); see also Eric Dannenmaier, Democracy in Development: Toward a Legal Framework for the Americas, 11 Tul. Envtl. L.J. 1, 5 (1997) ("In a society where individuals are not historically inclined to join a policy dialog directly, these [civil society] organizations are an important proxy for the public voice.").

236. Stephen Golub, From the Village to the University: Legal Activism in Bangladesh, in Many Roads to Justice, supra note 196, at 127, 133-34.

237. Stephen Golub, Participatory Justice in the Philippines, in Many Roads to Justice, supra note 196, at 197, 197-226.

238. Aldon Morris, Black Southern Student Sit-In Movement: An Analysis of Internal Organization, 46 Am. Soc. Rev. 744, 765 (1981).

239. See Gamson, supra note 181, at 89-108.

240. Craig Jenkins, Resource Mobilization Theory and the Study of Social Movements, 9 Ann. Rev. Soc. 522, 531 (1983).

241. Saul Alinsky, Reveille for Radicals 85-88 (Random House Inc. 1969) (1946). 
essential for real [rule of law] change. There must be a systematic focus on identifying and supporting 'agents of change' who have a driving will to reform." ${ }^{242}$

Social movement research has grown increasingly interested in the concept of framing. Erving Goffman, in his influential 1974 book, Frame Analysis: An Essay on the Organization of the Experience, outlined the process of individuals constructing their own reality by organizing events in a way that gives coherent meaning and guides their future action. ${ }^{243}$ In their efforts to create political will for reform, social movement actors are challenged to create enduring frames that diagnose the problems, articulate solutions, and then motivate the key populations. ${ }^{244}$ Framing includes the use of provocative words and language to mobilize action, with a notable example in the contemporary abortion debate being advocates' labeling of late-term procedures as "partial-birth abortion." ${ }^{245}$ As Robert Benford and David Snow put it, the social movement organizer's task is to create frames that will "move people from the balcony to the barricades." 246

\section{GRASSROOTS LEGAL ADVOCATES AND OPPORTUNITIES FOR FRAMING}

Grassroots legal advocates possess a uniquely advantaged position from which to devise compelling frames. Every paralegal's intervention to help a woman escape domestic violence and every attorney's successful effort to ensure inheritance rights for orphans is a victory not just for the individual clients but also for rule of law writ large. Properly leveraged, the stories emerging from this direct representation can explain a broader pattern of injustice in a dramatic and personal way, and thus has "framing" value far beyond the individual cases involved.

Blaming a dysfunctional system and its political leaders for a widespread lack of justice may seem intuitive, but research on the psychological phenomenon of "system justification" shows a common

242. Samuels, supra note 26, at 21.

243. Erving Goffman, Frame Analysis: An Essay on the Organization of the Experience 7 (1974).

244. Robert Benford \& David A. Snow, Framing Process and Social Movements: An Overview and Assessment, 26 Ann. Rev. Soc. 611, 615 (2000).

245. Anne W. Esacove, Dialogic Framing: The Framing/Counterframing of "Partial-Birth" Abortion, 74 Soc. Inquiry 70, 72 (2004).

246. Benford \& Snow, supra note 244, at 615. 
human predisposition to defend and justify the status quo, even among those who are most harmed by the existing system. ${ }^{247}$ Therefore, social movements must proceed around issues that are framed in sympathetic terms that are understandable to the population at large, the media, and the leaders who are being pressed to make changes. Donald Reitzes and Dietrich Reitzes point out that "symbolic interactionist" social psychologists and community organizers like Alinsky share the recognition that organized action comes about when private grievances are redefined as a community's shared social problem. ${ }^{248}$ Advocates who directly confront tangible ground-level instances of injustice are ideal frame articulators, since empirical credibility of the collective action frame is a key factor in whether the frame will have resonance. ${ }^{249}$ For example, arguing from experience that petty police bribery is not just a problem for one or two unlucky people, but rather a policy problem for an entire political district, provides the connectivity that transforms one legal client's complaint into a collective call for systemic change. ${ }^{250}$

These framing opportunities are not lost on legal advocates throughout the developing world, who demonstrate that there is no "either/or" choice to be made between the roles of providing direct legal representation and making calls for broader law reform. Many advocates have already shown their willingness to take the lessons learned, and the credibility earned, from representing individuals to provide community messages of education and empowerment. ${ }^{251}$ For example, Bangladeshi legal service providers are very active "framers" of justice issues. They investigate and expose issues including police torture, deaths in garment factories, dowry-related abuses, official responses to violent crimes against women and children, and a lack of secret balloting in village voting; they engage

247. See generally Gary Blasi \& John T. Jost, System Justification Theory and Research: Implications for Law, Legal Advocacy, and Social Justice, 94 Cal. L. Rev. 1119, 1119 (2006) (arguing that recent scientific research has revealed that the motive to defend and justify the social status quo, even among those who are seemingly most disadvantaged by it, often motivates human behavior).

248. Donald C. Reitzes \& Dietrich C. Reitzes, Alinsky in the 1980s: Two Contemporary Chicago Community Organizations, 28 Soc. Q. 265, 267 (1986).

249. Benford \& Snow, supra note 244, at 620 .

250. See, e.g., id. at 615 (citing several studies showing how movements identify "victims" of injustice and amplify their victimization into "injustice frames" created in advance of collective protest).

251. See, e.g., Manning, supra note 224, at 40 (discussing how the work of one legal services provider emboldens groups of the poor to act on their own behalf). 
in high-profile litigation to stop slum evictions, they actively cultivate the media, and they mobilize the community to conduct legislative lobbying. ${ }^{252}$ Advocates in a World Bank-sponsored program in Ecuador that included legal services programs for poor women, drew upon their ground-level experiences to generate a comprehensive report and a national workshop that led to broad reform recommendations. ${ }^{253}$ A Haitian legal advocacy group, Bureau des Avocats Internationaux, directly represents prisoners and other victims of human rights abuses while simultaneously seeking policy changes by publicizing their clients' plight within Haiti and to the U.S. government, international media and a network of Haitioriented U.S. activists. ${ }^{254}$

During the 1970s and 1980s, legal advocates in Peru, Chile, and Argentina responded to authoritarian governments by representing victims of political suppression and violence. Their public exposition of the abuse of their clients' rights led to international condemnation and supplied indigenous dissenters with empirically verifiable accounts of repression that countered government "frames" of fairness and freedom. ${ }^{255}$ The inherent conflict and personal stories of legal cases make for compelling media coverage on human rights grievances, as the Constitutional Rights Project in Nigeria discovered in the 1990s when it initiated several cases challenging the government's abuse of power. The Rights Project found that the media in that repressive environment gave coverage to court actions even when mass demonstrations were not reported on. ${ }^{256}$ Although the authoritarian governments ensured that these groups' legal challenges were not successful on an individual level, the widespread dissemination of the facts and arguments associated with the cases has been hailed as one of the most effective strategies for resistance to these regimes, since the advocacy process triggered and legitimated internal and external criticism of the governments. $^{257}$

252. Id., at 23-31; see also Golub, supra note 236, at 143 (describing a legal service provider's challenge to prisoner abuse and non-secret balloting).

253. McInerney, supra note 132 , at 140-42.

254. Brian Concannon, The Bureau des Avocats Internationaux, a VictimCentered Approach, in Effective Strategies for Protecting Human Rights 61, 62, 66 (David Barnhizer ed., 2001).

255. Fruhling, supra note 196, at 62-66.

256. Helen Hershkoff \& Aubrey McCutcheon, Public Interest Litigation, in Many Roads to Justice, supra note 196, at 283, 288.

257. Fruhling, supra note 196, at 64 . 


\section{A. The Framing of Galvanizing Events}

The framing process is particularly crucial when the aspiring movement is presented with a galvanizing moment or crisis. Highprofile grievances, whether the subject of formal litigation or not, are often ideal vehicles for providing both the galvanizing moment and the opportunity to frame the issue as an injustice applicable to a broad population. ${ }^{258}$ The most iconic U.S. example of both framing and galvanizing is the litigation challenging racial segregation in public schools, which culminated in the 1954 U.S. Supreme Court decision in Brown v. Board of Education. ${ }^{259}$ Ironically, the Brown decision had little immediate effect on school segregation, but it has been described by Richard Kluger as "the catalytic event that began the Second Reconstruction paralleling the one after the Civil War" and the parent of the mass civil rights movement. ${ }^{260}$

Similarly, an International Court of Justice ruling in 1971 against continued South African control and apartheid-themed occupation over an area then called "South-West Africa" triggered statements of support from church leaders, educators and tribal chiefs. Widespread strikes soon followed that led to more favorable labor agreements and continued the momentum toward the eventual liberation of "South-West Africa" into the independent nation of Namibia. ${ }^{261}$ Subsequent public interest litigation in southern Africa helped chip away at tangible components of apartheid, such as pass laws and prisoner abuse. ${ }^{262}$

\section{B. Repertoires of Contention}

In the case of widespread efforts to instill human rights and rule of law, human rights advocates have yet to determine the ideal

258. See William Felstiner et al., The Emergence and Transformation of Disputes: Naming, Blaming and Claiming, 15 Law and Soc'y Rev. 631, 639-40 (1980); see also Dakolias, supra note 137, at S45-S46 (noting that "test" cases in developing countries can engage the press and public).

259. Brown v. Board of Educ., 347 U.S. 483 (1954).

260. Richard Kluger, Simple Justice 753-54 (2004).

261. Gene Sharp, African Laborers Strike, Namibia, in Waging Nonviolent Struggle, supra note 209, at 205-216.

262. See Richard Abel, Politics by Other Means 60-65 (1995); see also Stephen Golub, Battling Apartheid and Building a New South Africa, in Many Roads to Justice, supra note 196, at 19, 24-30 (litigation challenging apartheid laws exploited the independence of the courts and the inherent contradictions of the discriminatory system). 
techniques for collective action ("repertoires of contention"). However, documented instances of citizens of the developing world mobilizing around rights issues may provide a glimpse of the future forms of collective action that will be employed to expand and enforce rights guarantees.

A legal-clinic-turned-law-reform organization in Ghana organized public marches, petition drives, and litigation to challenge a requirement that cash be paid up front before accessing health care. $^{263}$ Senegalese women mobilized against female genital mutilation by lobbying religious and traditional leaders-among other tactics, through the use of dramatic displays of razor blades formerly used in the procedure-and led the successful effort to legally ban the practice in several villages. ${ }^{264}$ In South Africa, organized women's groups played a key role in ending apartheid through direct action including strikes, civil disobedience and protests, ${ }^{265}$ and then engaged in nonviolent disruptions of constitutional negotiations until women were accorded a significant role in the process. ${ }^{266} \mathrm{~A}$ Chilean environmental advocacy group sued and halted a concession of public land to the timber industry. ${ }^{267}$

Although public interest litigation may seem like an obvious choice for legal advocates, social movement history suggests caution before adopting lawsuits as a reform strategy. Litigation, because it can be costly, slow, and overly reliant on a few elite attorney actors is not always the best repertoire of contention for a movement. ${ }^{268}$ Empirical analysis of law reform efforts in the U.S. have concluded that the courts tend to follow behind popular reform movements, not

263. White, supra note 217 , at 168-69.

264. Sarah Crowe \& Molly Melching, UNICEF, Ending female genital mutilation and cutting in Senegal, (Nov. 24, 2005), http://www.unicef.org/infobycountry/senegal_30046.html.

265. Gay W. Seidman, "No Freedom Without the Women:" Mobilization and Gender in South Africa, 1970.1992, 18 Signs 291, 302 (1993); see also Pamela E. Brooks, Boycotts, Buses, and Passes 202-38 (2008) (describing particularly significant individuals and occurrences in the South African women's movement to end apartheid).

266. Gay W. Seidman, Gendered Citizenship: South Africa's Democratic Tradition and the Construction of a Gendered State, 13 Gender and Soc'y 287, 294 (1999).

267. Dannenmaier, supra note 235, at 31.

268. See Michael McCann \& Helena Silverstein, Rethinking Law's Allurements: A Relational Analysis of Social Movement Lawyers in the U.S., in Cause Lawyering 261, 262-64 (Austin Sarat \& Stuart Scheingold eds., 1998). 
initiate them. ${ }^{269}$ In contrast, the extra-institutional pressure of protests has been shown to have a demonstrable effect on policy outcomes. ${ }^{270}$ Even an important lawsuit does not call upon the movement actors to publicly demonstrate their depth and breadth, an important component of advocacy that Charles Tilly has labeled "WUNC" (Worthiness, Unity, Numbers, Commitment) displays. ${ }^{271}$

\section{Alternatives to Litigation}

When litigation is not the ideal choice, legal actors can turn to other repertoires of contention. In 2007, lawyers in Pakistan conducted high-profile street demonstrations against President General Pervez Musharraf's attempts to dismiss the country's chief justice and impose emergency rule. ${ }^{272}$ Lucie White writes of an example of how lawyers teamed with traditional social movement organizers to educate and empower black villagers to block a forced removal in apartheid South Africa. ${ }^{273}$ Frank Bloch has chronicled how law school clinics have increased access to justice, partly through legal literacy programming, in South America, Africa, and South and East Asia. ${ }^{274}$ An historical example of the key nonlitigation role that lawyers can play in framing a grievance and triggering broader action is found in the removal of Guatemalan dictator General Jorge Ubico y Castaneda in 1944, when 45 lawyers wrote a series of articles in a Guatemala City newspaper and became the first to ever publicly call out the General about corruption in the judiciary. The articles triggered teacher and student protests, demonstrations, and a public strike. Within a month, Ubico resigned. ${ }^{275}$

Multi-country reviews of legal advocacy programs by the World Bank $^{276}$ and the Ford Foundation ${ }^{277}$ show that rule of law

269. See Gerald N. Rosenberg, The Hollow Hope: Can Courts Bring About Social Change? 70-71 (2d ed. 2008).

270. Meyer \& Minkoff, supra note 180, at 1479.

271. Tilly, supra note 170 , at 4 .

272. Jane Perlez \& David Rhode, Pakistan Attempts to Crush Protests By Lawyers, N.Y. Times, Nov. 6, 2007, at A1.

273. Lucie E. White, To Learn and Teach Lessons From Driefontein on Lawyering and Power, 1988 Wis. L. Rev. 699, 723-38 (1988).

274. Frank S. Bloch, Access to Justice and the Global Clinical Movement, 28 Wash. U. J.L. \& Pol'y 111, 127-28 (2008).

275. Gene Sharp, Ousting a Guatemalan Dictator, 1944, in Waging Nonviolent Struggle, supra note 209, at 149, 149-155.

276. Manning, supra note 224. 
interventions work best when they support law reform advocates who leverage their credibility and knowledge from grassroots representation to use a variety of techniques to make convincing arguments for reform. Cambodian legal service providers, informed by the daily experience of representing poor tenants and landowners, helped develop a proposal for land law reform. ${ }^{278}$ South African legal advocates supplemented rights-oriented litigation with nonviolent resistance to attempts to remove black individuals to "homelands," and helped inform and empower the country's labor movement, which played a key role in opposing apartheid. ${ }^{279}$ Burkina Faso advocates launched legal literacy programs, ${ }^{280}$ Chinese legal service providers engaged in both high-profile litigation and public reporting on behalf of women workers, ${ }^{281}$ and Croatian advocates engaged in community human rights education. ${ }^{282}$

Given the prevalence of settings in the developing world where formal litigation is overshadowed by informal application of customary or religious law, it is important to note the transformative opportunities presented by rights advocacy in these traditional forums. Although traditional legal forums may be imperfect, they are not static. As one observer stated: "They are continuously evolving socio-economic cultural constructs affected and altered by internal and external forces which place pressures on those within." 283 Inside and outside of formal legal systems, indigenous advocates are positioned to access a variety of repertoires of contention to pressure for change, and some are already doing so on a scale limited by their scant resources. ${ }^{284}$

\section{Fruhling, supra note 196.}

278. Manning, supra note 224, at 46; see also USAID, Defending Citizens' Land Rights, http://www.usaid.gov/stories/cambodia/ss_cb_legal.pdf (last visited Oct. 18, 2009) (discussing the Community Legal Education Center's success in protecting the land rights of local Cambodian residents).

279. Golub, supra note 262 , at 32-33.

280. Id. at 50.

281. Manning, supra note 224, at 52; see also Aubrey McCutcheon, Contributing to Legal Reform in China, in Many Roads to Justice, supra note 196, at 181-84, 195 (discussing work done by the Peking Women's Centre and the Qianzi Women's Centre in promoting women's legal rights).

282. Manning, supra note 224, at 53-54.

283. Justice for the Poor: Kenya, World Bank, Gender Action Plan: Preliminary Assessments of Women's Access to Land Rights in Agricultural Communities in Kenya 3 (2008).

284. See Atsango Chetsoni et al., Swedish Int'l Dev. Cooperation Agency, Promoting Women's Rights and Enhancing Gender Equality in Kenya 24-26 (2006); see also Chopra, supra note 87 , at 4 (detailing the small scale project that 
D. Conclusion

Just as there is no boilerplate set of repertoires of contention, there is no instruction manual setting out a step-by-step sequence for social movements. But the research of David Meyer and Debra Minkoff on African American civil rights movements, ${ }^{285}$ among others, suggest that movement actors would ideally build organizational strength and a record of issue framing while preparing for "galvanizing moments" of ripe opportunity for protests and rapid change. Viewed through this prism, a developing nation's rule of law movement calling for broader and deeper recognition of women's rights, for example, is likely now in a stage preceding dramatic protests such as the bus boycotts or sit-ins of the U.S. civil rights movement or the mass pro-democracy demonstrations in Eastern Europe and the Soviet Union. At this stage, the key rule of law movement actors are the legal services providers and grassroots law reform advocates who are building expectations of justice, forging networks of supporters, and framing the case for human rights. By supporting these efforts, rule of law funders can play a critical role in laying the foundation for movement actors to seize the opportunity for substantial, transformative change.

\section{CONCLUSION}

A little over one year after being driven off her land, Leah J. was attending a support group meeting for HIV patients in Eldoret when she heard about a new one-attorney legal aid program that was connected with the HIV treatment center. Leah told her story to the attorney, Juliet Mule, who immediately went to Kenya's High Court in Eldoret and obtained an order allowing Leah to withdraw 25,000 Kenyan shillings, about $\$ 322$ U.S., from a bank account that was in Leah's husband's name. Leah is using the money to rent a home and pay the children's school fees, as well as for the transportation and search fees she needs to help Mule document title to the land owned by Leah's husband and taken by his family.

When Leah has the family land restored to her, she dreams of starting a business selling second-hand shoes. She knew all along she had the right to the marital property, but she also had no idea that a poor person like her could ever hope to enforce that right. When she

the Kenya National Human Rights Commission undertook to find innovative solutions for women facing disinheritance).

285. Meyer \& Minkoff, supra note 180, at 1484. 
relates the positive turn in her fortunes after finding a path to justice, Leah's voice becomes stronger. "I've talked to the other widows to let them know," she says. ${ }^{286}$

Juliet Mule is letting other widows know, too. She has spoken about legal rights to support groups for people living with HIV/AIDS, and is eager to make presentations to schools and community groups, conduct media outreach, and to train local elders and other community leaders in the law. But Mule's fledgling organization, the Legal Aid Centre of Eldoret, ${ }^{287}$ is just a two-person shop funded solely by small donations from private U.S. supporters, and Mule spends her days and evenings responding to the glut of legal emergencies like Leah's. ${ }^{288}$

Juliet Mule, like countless other direct legal services providers and community-based rights advocates across the developing world, stands ready to help grow the elusive political will for the rule of law. Mule and her contemporaries are living proof that significant elements of successful rule of law social movements are already in place: political opportunity exists in many developing countries, movement actors are ready to frame justice issues so as to garner popular support, advocates like Mule and their clients like Leah J. are forging networks of both advocates and the aggrieved, and there are many proven models of effective repertoires of contention for law reform. After two decades of misguided investments, rule of law funders must seize this opportunity to support social movement actors who can shape and deliver rule of law from the grassroots up.

286. Leah J., supra note 1.

287. In his role as director of operations for the Indiana-Kenya Partnership (also known as the Academic Model for Providing Access to Healthcare (AMPATH)), the HIV care program in western Kenya referred to here, the author helped found the Legal Aid Centre of Eldoret (LACE).

288. Interview with Juliet Mule, in Eldoret, Kenya (June 8, 2009) (on file with author). 